\title{
Vertical distribution of microbiological and hydrographic-chemical parameters in different areas of the Baltic Sea
}

\author{
Gerhard Rheinheimer, Klaus Gocke, Hans-Georg Hoppe
}

Institut für Meereskunde an der Universität Kiel, Düsternbrooker Weg 20, D-2300 Kiel, Federal Republic of Germany

\begin{abstract}
During 2 cruises with RV 'Poseidon in August 1982 and August 1986 in the Baltic Sea, a series of vertical profiles between the Fehmarn Belt and the northern Gulf of Bothnia was investigated. Among the bacteriological variables determined were total bacteria number, bacterial biomass, saprophyte count on different media, turnover rate and maximum uptake velocity of glucose, and, for some stations, extracellular enzyme activity. Highest bacteria numbers and biomass values were always found in the photic zone. In the colder waters below the mixed layer all microbiological values decrease. In the boundary layer of the central Gotland Sea, especially between the oxic and anoxic hydrogen sulfide-containing zone bacteriological values increase markedly. In the water layer above the sediment another increase of bacterial stock and activity measurements was occasionally determined. In the Gulf of Bothnia, where the whole water column is sufficiently aerated, only in bottom waters may an increase in bacterial values occur. Depending on the oxygen regime, bacterial nitrogen conversion is very different in the individual areas of the Baltic Sea. Comparison of nitrite and nitrate concentrations shows that nitrification in the Gotland Deep occurs down to the chemocline. Below this a narrow denitrification zone (about $10 \mathrm{~m}$ ) was found in which nitrate almost completely disappears. In the Gulf of Bothnia, as a result of the favorable oxygen conditions, the nitrification zone extends down to the sea bottom.
\end{abstract}

\section{INTRODUCTION}

The Baltic Sea is an extension of the Atlantic Ocean with narrow, relatively shallow connections to the North Sea. Numerous freshwater affluents lead to a great reduction of the salinity. The western Baltic Sea is an area of strong water exchange which determines its hydrographic, chemical and biological conditions. The inflow of North Sea water, however, decreases considerably in the central Baltic Sea, where the deeper regions are often anoxic. Hydrogen sulfide is generally present in the Gotland Deep and Faroe Deep below 120 to $140 \mathrm{~m}$. Only after periods of particularly strong salt water advections from the North Sea can oxygen-rich water temporarily penetrate into these depths.

The stratification of water masses of different origin is a key factor for microbiological and chemical processes in the Baltic Sea. Its stability and duration varies considerably in the different regions. The establishment of a chemocline (oxic-anoxic interface) in some of the deeper basins is a consequence of the permanent halocline. The halocline descends from about $20 \mathrm{~m}$ depth in the Western Baltic Sea to about $70 \mathrm{~m}$ in the Gulf of Bothnia. The positions of the chemocline and the halocline in the vertical profile are, however, not identical, because the chemocline depends on the balance of microbial oxidation and reduction processes of sulfur in the environment. During the warm season the warm surface water (mixed layer) is separated from the waters beneath by a thermocline. The depth of the thermocline shifts from $20 \mathrm{~m}$ in the Western Baltic Sea to about $10 \mathrm{~m}$ in the Gulf of Bothnia. Later in the year this thermal stratification is destroyed by wind-dependent mixing processes. During early summer, when the thermocline is re-established, a zone of cold socalled 'winter water' remains between the thermocline and the halocline which borders the warmer bottom water. This complicated system of vertical stratification and the changes which it undergoes in the longitudinal dimension are responsible for many phenomena of bacteria distribution in the central parts of the Baltic Sea. In the Gulf of Bothnia, where a chemocline and a typical zone of 'winter water' are lacking, the patterns of bacteria distribution are less complicated. The 
biological and physical zonation of the Baltic water column has been described in detail by Gundersen (1981).

The hydrographic and chemical conditions of the open Baltic Sea have already been studied intensively (Nehring 1981, Nehring \& Francke 1981, Francke \& Nehring 1986). Microbiological investigations have been carried out in this large brackish water area only to a far lesser extent. Apart from the coastal waters, such investigations have been made mainly in the western part (Rheinheimer 1984). In the central Baltic Sea microbiological studies have been performed by e.g. Finnish (Seppänen \& Voipio 1971) and Soviet/ Swedish expeditions (Tsiban et al. 1980), as well as during cruises from the Institute for Marine Research in Kiel, F. R. Germany (Gocke 1977, Dawson \& Gocke 1978, Gocke \& Hoppe 1982a, b). In the open waters of the Gulf of Bothnia such studies have been largely lacking.
To improve our knowledge of the bacteriological situation in areas farther from the coast, 2 research cruises with the RV 'Poseidon' were undertaken from Kiel. The first cruise (August/September 1982) led to the northern Gulf of Bothnia, and the second (August 1986) to the south of Finland (Fig. 1). At 10 and 5 stations, respectively, vertical distributions of bacteria (number and biomass) as well as their activity (turnover rate and maximum uptake of glucose and for some stations also extracellular enzyme activity) were determined. Further studies concerned changes in the bacterial population dependent on the $\mathrm{O}_{2} / \mathrm{H}_{2} \mathrm{~S}$ regime, and nitricifaction and denitrification processes. For the first time, microbiological investigations using the same methods were carried out over the entire length of the Baltic Sea. It was the aim of these cruises to provide an overall view of the bacteriological events and to define their relationship to the prevailing hydrographic conditions.

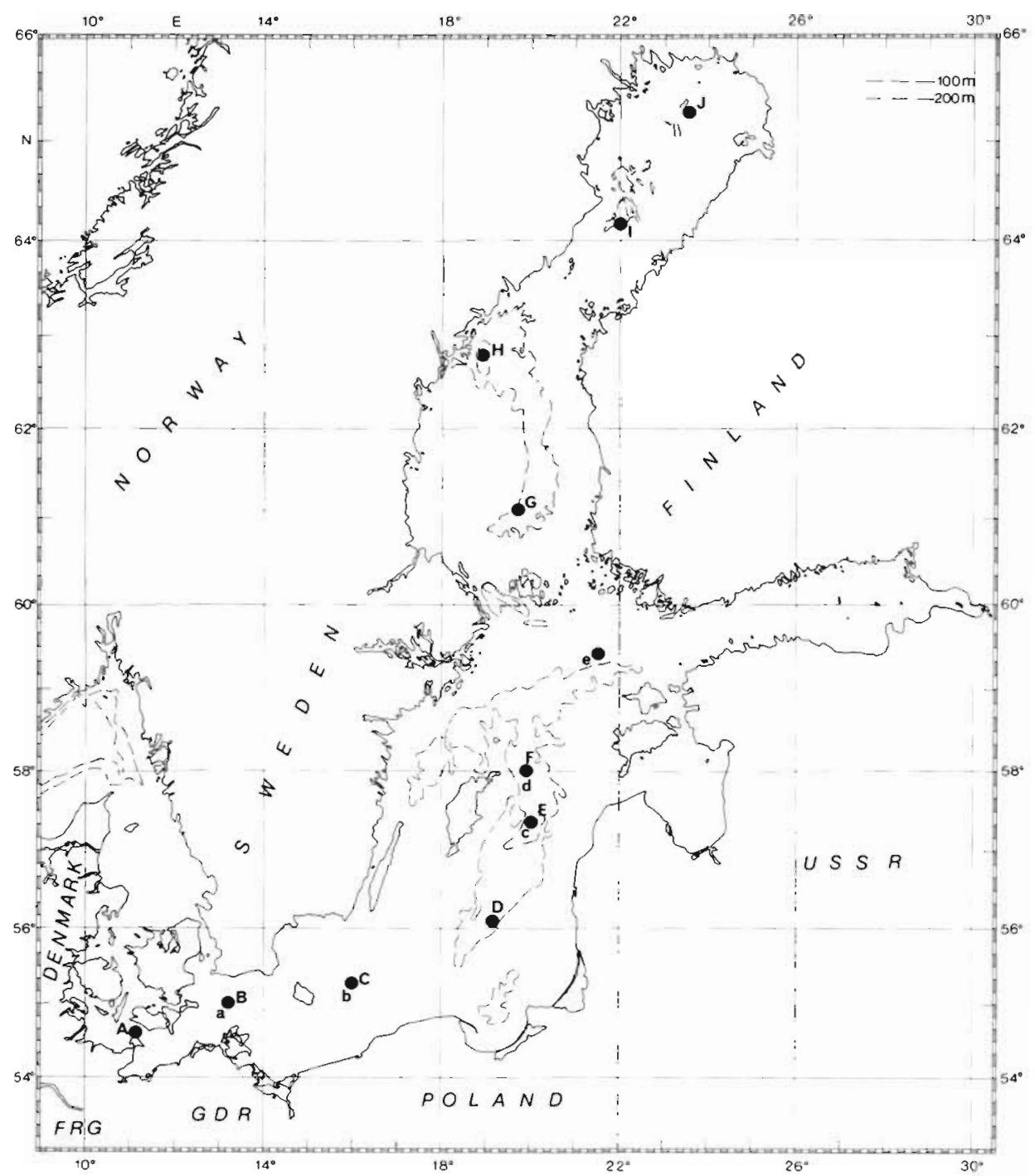

Fig. 1 Location of sampling stations in the Baltic Sea. Capital letters: cruise from 16 Aug to 4 Sep 1982; small letters: cruise from 11 Aug to 24 Aug 1986 


\section{MATERIAL AND METHODS}

On the 1982 cruise, a series of profiles was taken from 16 to 28 August at 10 stations (Stns A to J; Figs. 2 to 11) from the western Baltic to the northern Gulf of Bothnia. An additional profile was obtained at Stn B (Arkona Basin) on 4 September. On the 1986 cruise, a series of profiles was taken from 12 to 19 August at 5 stations (Stns a to e; Figs. 12 to 16) in the western and central Baltic. An additional profile was obtained at Stn a (Arkona Basin) on 24 August.

Hydrographical and chemical variables. Water temperature and salinity were determined with the 'Multisonde Kiel' from the firm ME, Trappenkamp, Germany. Water samples for determination of the further variables were obtained with 51 hydrographical Niskin samplers. Analyses were conducted in the ship laboratory immediately after sampling. For determination of the different variables the following methods were used: oxygen according to Winkler (Grasshoff 1976); hydrogen sulfide according to Grasshoff (1976); ammonia according to Grasshoff $(1964)$; nitrite and nitrate according to Grasshoff (1968); orthophosphate according to Murphy \& Riley (1962); silicate according to Koroleff (Grasshoff 1976); chlorophyll a according to SCOR-UNESCO (1966); $\mathrm{BOD}_{7}$ according to Deutsche Einheitsverfahren.

Microbiological variables. Total bacteria numbers and bacterial biomass: Water samples were taken down to a depth of $150 \mathrm{~m}$ with autoclaved 0.7 l champagne bottles mounted on modified ZoBell samplers. At greater depths sterile plastic bags with bacteriological Niskin samplers (General Oceanics, Miami, USA) were used.

For determinations of total bacteria numbers (TBN), immediately after sampling $100 \mathrm{ml}$ of water were transferred into brown glass bottles and preserved with $2 \mathrm{ml}$ freshly filtered formalin $(37 \%)$. Fluorescence microscopical investigations took place in the laboratory of the Kiel Institute according to Zimmermann (1977). Nuclepore filters $(0.2 \mu \mathrm{m}$ pore size) previously stained with $0.004 \%$ solution of sudan black were utilized for filtration. Bacteria cells were stained with a $0.01 \%$ solution of acridine orange for 3 min and counted with a standard Zeiss microscope equipped with an epifluorescence apparatus. From each slide 54 visual fields were assessed for counts. Bacterial lengths were measured with a graduated eyepiece. According to form and size 9 different groups were classified (Rheinheimer 1977, Zimmermann 1977). Cell volume was calculated according to Daubner (1972). For conversion from volume to carbon content a factor of $1 \times 10^{-7} \mu \mathrm{g} \mathrm{C} \mu \mathrm{m}^{-3}$ was applied. The mean bacterial cell volume of each water sample was also determied. In the literature conversion factors can be found which are between 0.86 (Ferguson \& Rublee 1976) and
$5.6 \times 10^{-7} \mu \mathrm{g} \mathrm{C} \mu \mathrm{m}^{-3}$ (Bratbak 1985). Thus the value used un the present work leads to somewhat conservative bacteria biomass figures.

Saprophyte counts: For saprophyte counts the yeast extract-peptone agar medium ZoBell $2216 \mathrm{E}$ was employed, using $750 \mathrm{ml}$ aged seawater and $250 \mathrm{ml}$ distilled water (ZS). In addition the same medium was prepared with $250 \mathrm{ml}$ aged seawater and $750 \mathrm{ml}$ distilled water $(Z B)$ and with $1000 \mathrm{ml}$ of tap water (ZL). The media were inoculated immediately after sampling. Incubation temperature was $20^{\circ} \mathrm{C}$ and the resulting colonies were counted after $14 \mathrm{~d}$

The saprophyte counts represent a small group of actively metabolizing bacteria which immediately react to changes in the nutrient supply. Thus, they are an important indicator group.

Turnover rate and maximum uptake velocity of glucose: Water samples for determinations of turnover time $\left(T_{m}\right)$ and maximum uptake velocity $\left(V_{m}\right)$ of glucose were taken with thoroughly cleaned non-sterilized oceanographic water samplers (5l Niskin bottles). Sterilized equipment was used for further processing which was commenced immediately after sampling.

For determining the turnover rate triplicate $100 \mathrm{ml}$ samples and a formalin-killed blank $(0.3 \mathrm{ml}$ formalin) received $20 \mu$ of radioactive solution containing $0.1 \mu \mathrm{Ci}$ of ${ }^{14} \mathrm{C}$-glucose (uniformly labelled, Amersham Buchler). The final concentration of glucose was $0.25 \mu \mathrm{g} \mathrm{C}$ $\mathrm{l}^{-1}$. For determining the maximum uptake velocity an analogue procedure was performed. To the samples was pipetted $200 \mu$ of radioactive solution containing $1 \mu \mathrm{Ci}$ of ${ }^{14} \mathrm{C}$-glucose and ${ }^{12} \mathrm{C}$-glucose. The final concentration of the added glucose was $20 \mu \mathrm{g} \mathrm{C} \mathrm{l}^{-1}$. Earlier studies in the Baltic Sea (Gocke 1977) have shown that this concentration was above the saturation concentration of the glucose uptake systems of the natural bacterial populations.

The bottles were incubated at in situ temperature $\left( \pm 1 \mathrm{C}^{\circ}\right)$ in an agitated water bath. Incubation times were $2 \mathrm{~h}$ for samples above and 3 to $4 \mathrm{~h}$ for those below the thermocline. Reactions were stopped by adding $0.3 \mathrm{ml}$ formalin. Then the samples were filtered through membrane filters ( 0.2 um pore size, Sartorius), washed with filtered seawater and assayed for radioactivity by liquid scintillation.

For the samples from the 1986 cruise ambient $\mathrm{O}_{2}$ or $\mathrm{H}_{2} \mathrm{~S}$ concentrations were maintained during incubation. The glass-stoppered $100 \mathrm{ml}$ bottles (nominal volume) were completely filled with sample water exactly in the manner as for $\mathrm{O}_{2}$ or $\mathrm{H}_{2} \mathrm{~S}$ determinations. Then the required amount of the radioactive liquid was introduced by means of a syringe equipped with a long needle. The radioactive solution was previously deoxygenated by passing $\mathrm{N}_{2}$ through it for $10 \mathrm{~min}$. All other steps were the same as described above. 
Extracellular enzyme activity of bacteria (EEA): Water for EEA determinations was taken from the same samplers which were also used for the bacterial substrate uptake. Measurements of EEA were performed with the aid of model substrates (leucine-methylcoumarinylamide [Leu-MCA], substrate for aminopeptidases; methylumbelliferyl- $\beta$-D-glucopyranoside [MUF- $\beta$-glu], substrate for $\beta$-glucosidases). The method with its advantages and disadvantages has been described in detail by Hoppe (1983). Similar to the method in substrate uptake studies (Wright \& Hobbie 1966), increasing concentrations of the model substance are given to the water sample. The breakdown of these substances is dependent on the extracellular enzyme activity of the bacteria. This is measured by means of the fluorescence which develops during the hydrolysis of the model substance. The breakdown of the model substrate takes place as a rule according to a first order enzyme reaction, so that the maximum hydrolysis velocity of the extracellular enzymes $\left(V_{m}\right)$ can be calculated.

Water samples for EEA determinations were incubated at in situ temperature. Incubation periods were between 4 and $8 \mathrm{~h}$. The unit of $V_{m}$ for peptidases is $\mu \mathrm{g}$ $\mathrm{C}_{\text {leu }} \mathrm{I}^{-1} \mathrm{~h}^{-1}$, and designates the amount of leucine carbon which is released from the model substance by the bacteria in 11 water sample per hour.

\section{RESULTS}

The most important results of the hydrographic, chemical and microbiological investigations are presented in Figs. 2 to 16. Further data are given in Tables 1 and 2 .

According to their hydrographic and microbiological conditions, 6 areas of the Baltic Sea may be differentiated (Fig. 1): (1) Fehmarn Belt (Stn A); (2) Arkona Basin (Stns B, a); (3) Bornholm Basin to the southern Gotland Basin (Stns C, D and b); (4) Gotland Deep and Faroe
Deep (Stns E, F and $c_{1}$ d); (5) Teili Deep (Stn e); (6) Gulf of Bothnia (Stns G to J).

Capital letters stand for the year 1982, small letters for 1986.

\section{Temperature and salinity}

In the Fehmarn Belt the temperature on $16 \mathrm{Aug} 1982$ decreased from $16.67{ }^{\circ} \mathrm{C}$ at $2 \mathrm{~m}$ to $8.08{ }^{\circ} \mathrm{C}$ at a depth of $27 \mathrm{~m}$. In contrast the salinity rose from 18.40 to $28.36 \%$ (Fig. 2).

In the Arkona Basin beneath the mixed layer very strong changes in these variables occurred on 17 Aug 1982 (Fig. 3). The highest temperature, $17.92^{\circ} \mathrm{C}$, was measured at $2 \mathrm{~m}$, the lowest was $8.13^{\circ} \mathrm{C}$ at $27 \mathrm{~m}$. This corresponded approximately to the conditions in the Fehmarn Belt on the previous day. Below $27 \mathrm{~m}$ the temperature rose again sharply and reached $16.68^{\circ} \mathrm{C}$ at $41 \mathrm{~m}$ i.e. only $1.24^{\circ} \mathrm{C}$ lower here than at the surface. Salinity rose from $7.98 \%$ at $2 \mathrm{~m}$ to $16.25 \%$ at $40 \mathrm{~m}$, with only small differences down to $27 \mathrm{~m}$. These unusual conditions are caused by inflowing currents when warm water with high salinity from the Kattegat slips beneath the less saline Baltic Sea water. A repeat of the measurements on 4 Sept 1982 showed a similar temperature profile. On 12 Aug 1986 the surface water had a temperature of $17.3^{\circ} \mathrm{C}$. Below the mixed layer a clear increase, from $5.4^{\circ} \mathrm{C}$ at $22 \mathrm{~m}$ to $11.0^{\circ} \mathrm{C}$ at $40 \mathrm{~m}$, was again noted, and the salinity rose from 7.8 to $17.7 \%$ (Fig. 12). On 24 Aug 1986 there was only a relatively small temperature increase from $7.1^{\circ} \mathrm{C}$ at $26.5 \mathrm{~m}$ to $9.5^{\circ} \mathrm{C}$ at $40 \mathrm{~m}$. The salinity here reached $20.0 \%$. These data clearly show the rapid hydrographic changes occurring in this area.

In the Bornholm Basin the typical temperature and salinity distribution in the Baltic proper was established (Figs. 4 and 13). Beneath the mixed layer, which reached down to a depth of $20 \mathrm{~m}$ the temperature rapidly dropped to below $5^{\circ} \mathrm{C}$ and at $50 \mathrm{~m}$ depth it was
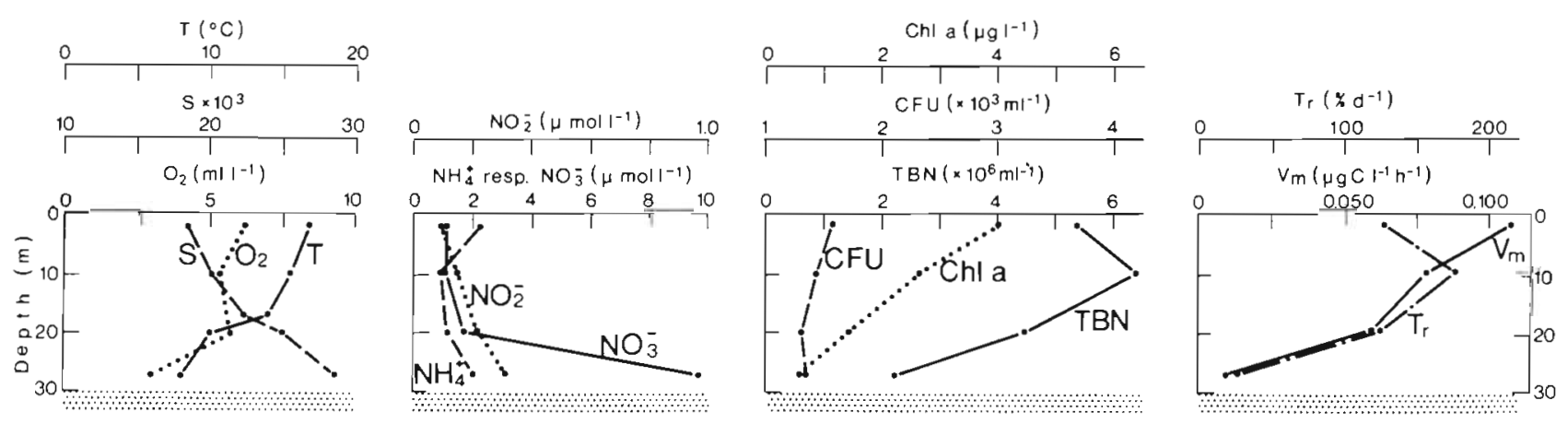

Fig. 2. Vertical distribution of oceanographical, chemical and microbiological parameters at Stn A (Fehmarn Belt) on 16 Aug 1982. CFU: saprophytic bacteria (colony forming units); TBN: total bacteria number; $V_{m}$ : maximum velocity of glucose; $T_{r}$ : turnover rate of glucose. Except for station and date, legend applies also to all subsequent figures 

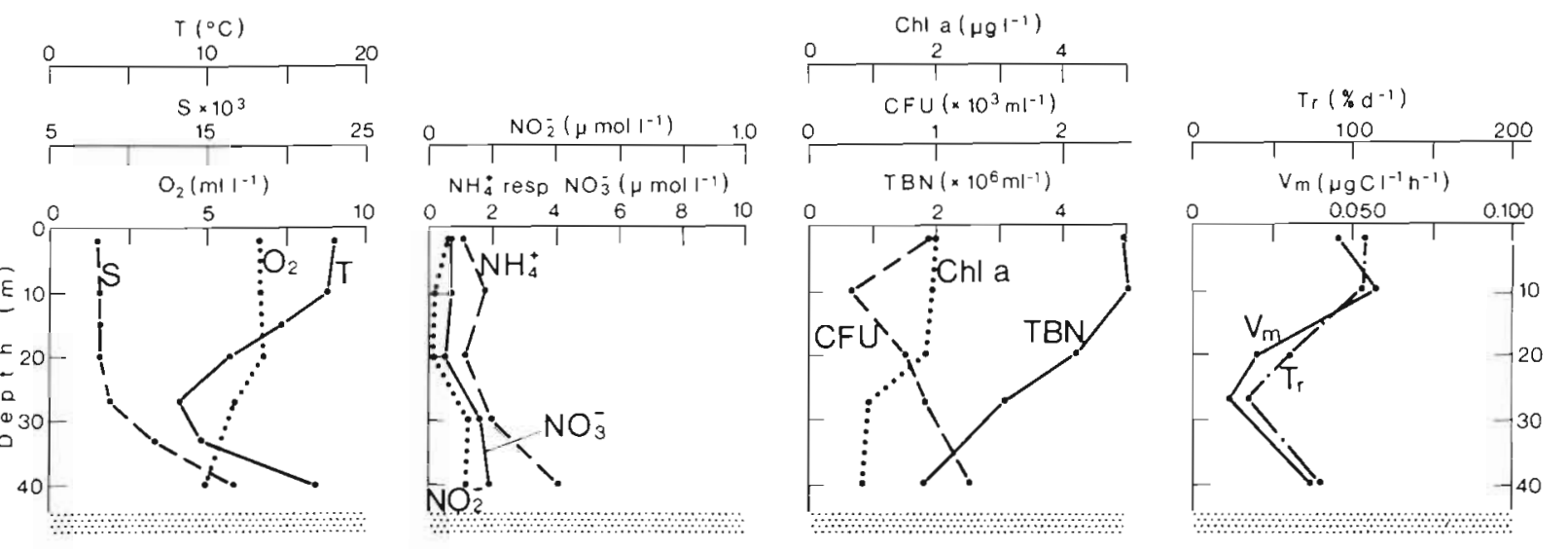

Fig. 3. Stn B (Arkona Basin), 17 Aug 1982
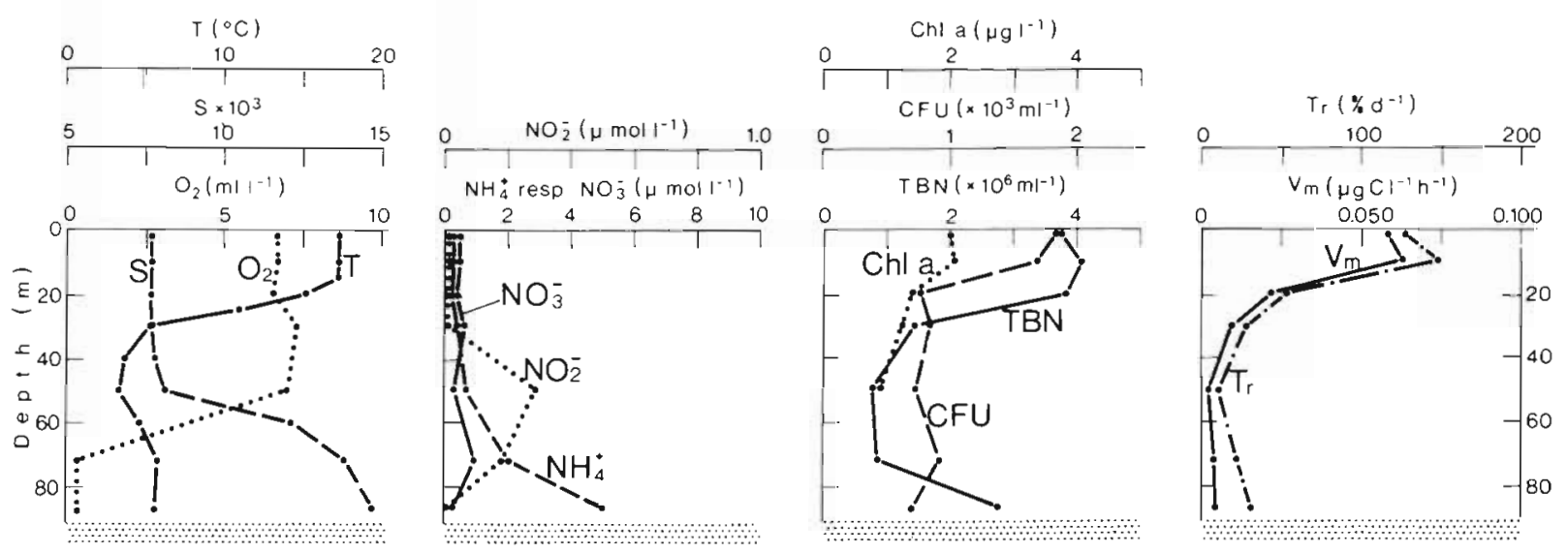

Fig. 4. Stn C (Bornholm Basin), 18 Aug 1982
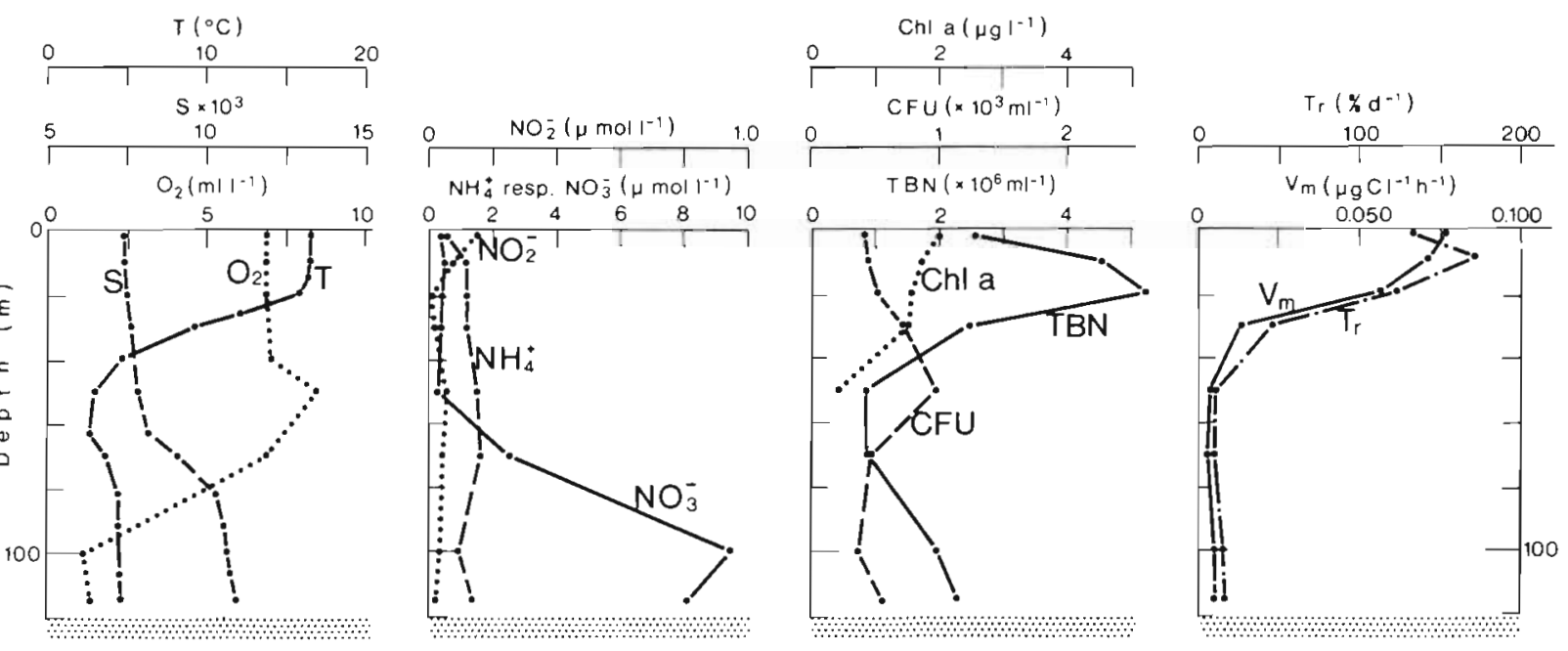

Fig. 5. Stn D (southern Gotland Deep), 19 Aug 1982

3.30 and $1.90^{\circ} \mathrm{C}$ in 1982 and 1986 respectively. Below this 'winter water' the temperature rose again at $70 \mathrm{~m}$ depth to 5.8 and $4.5{ }^{\circ} \mathrm{C}$ respectively. The salinity showed little change down to $50 \mathrm{~m}$, then rose to 14.7 and $15.3 \%$ respectively at $85 \mathrm{~m}$ depth. In the southern
Gotland Basin on 19 Aug 1982 the temperature and salinity distribution was similar. Only the salinity maximum here was clearly lower with $11.0 \%$ (Fig. 5).

In the region of the Gotland Deep and Faroe Deep conditions down to $100 \mathrm{~m}$ were similar to those of the 

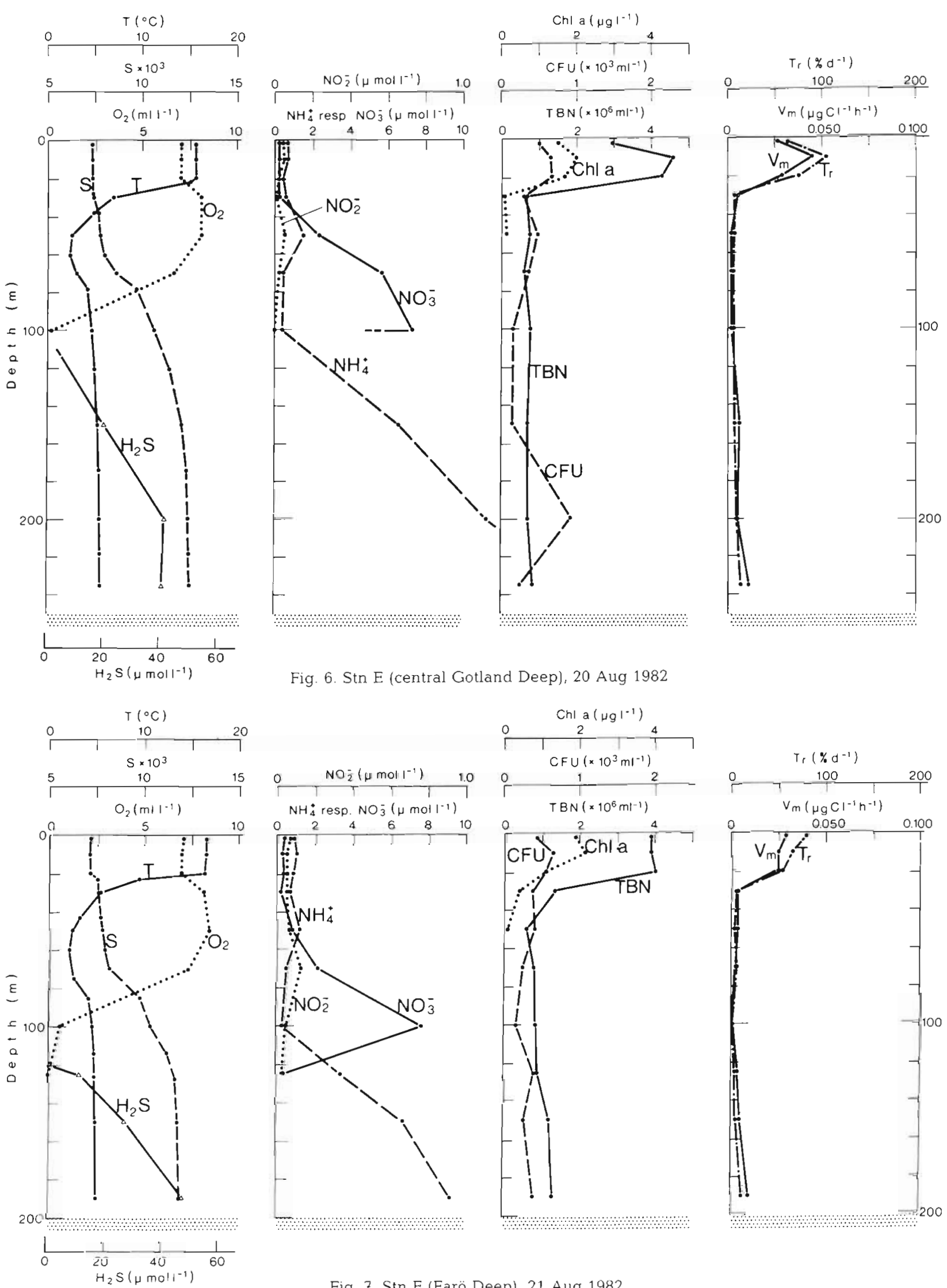

Fig. 6. Stn E (central Gotland Deep), 20 Aug 1982
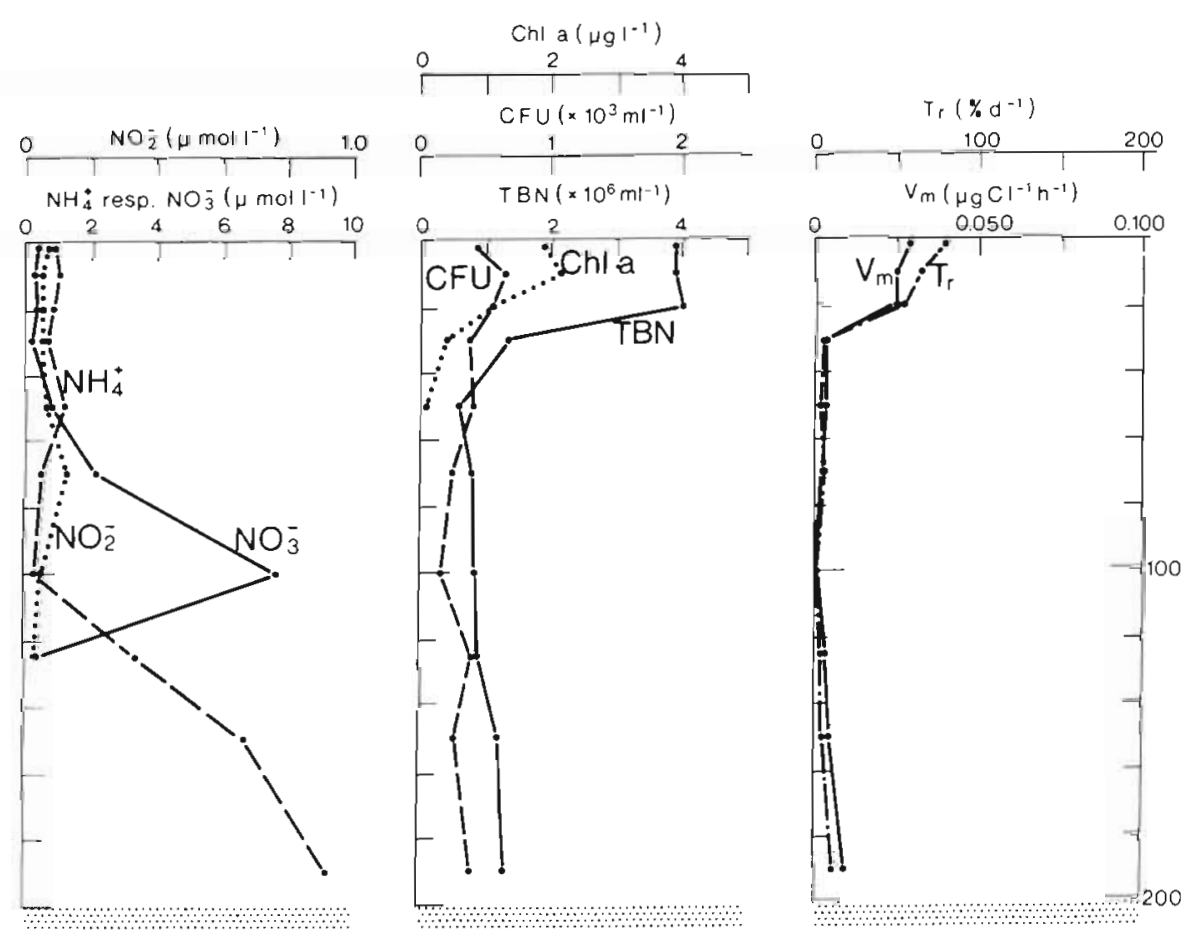

Fig. 7. Stn F (Farö Deep), 21 Aug 1982 

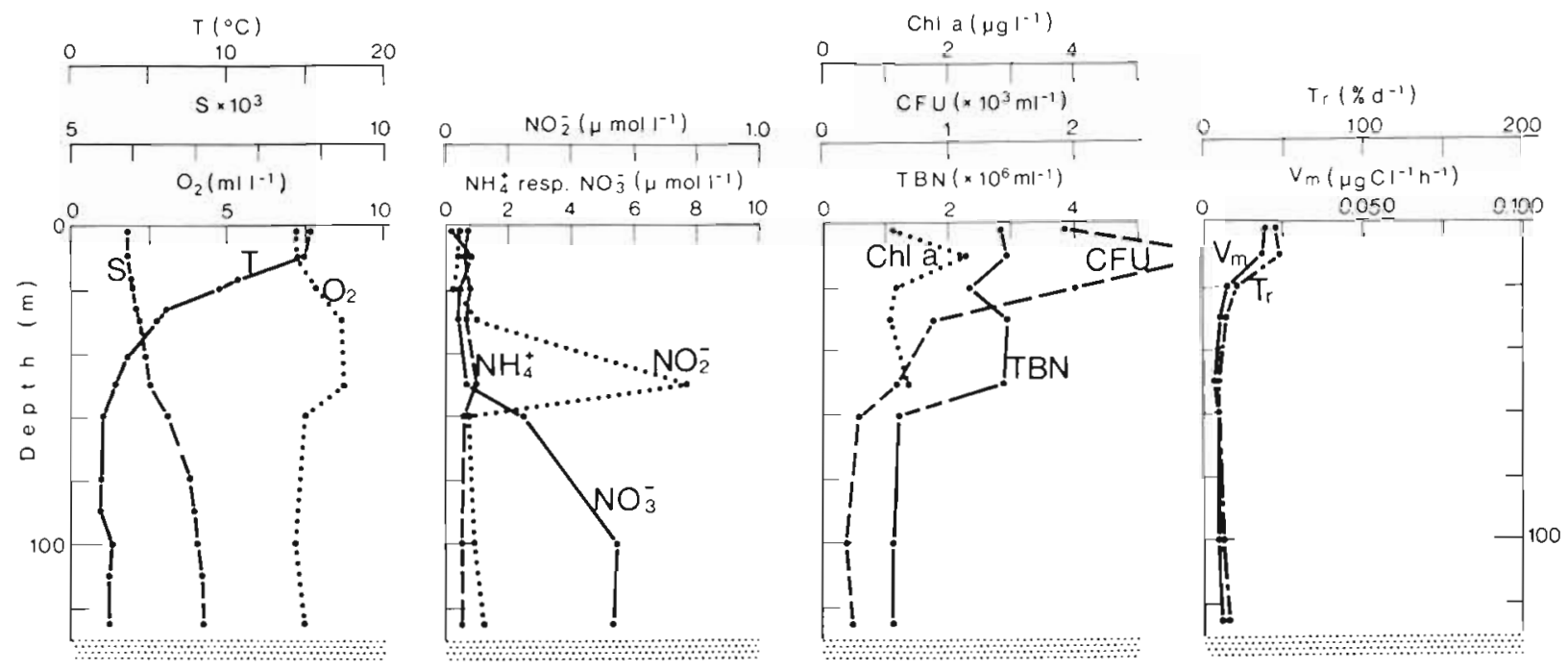

Fig. 8. Stn G, 25 Aug 1982
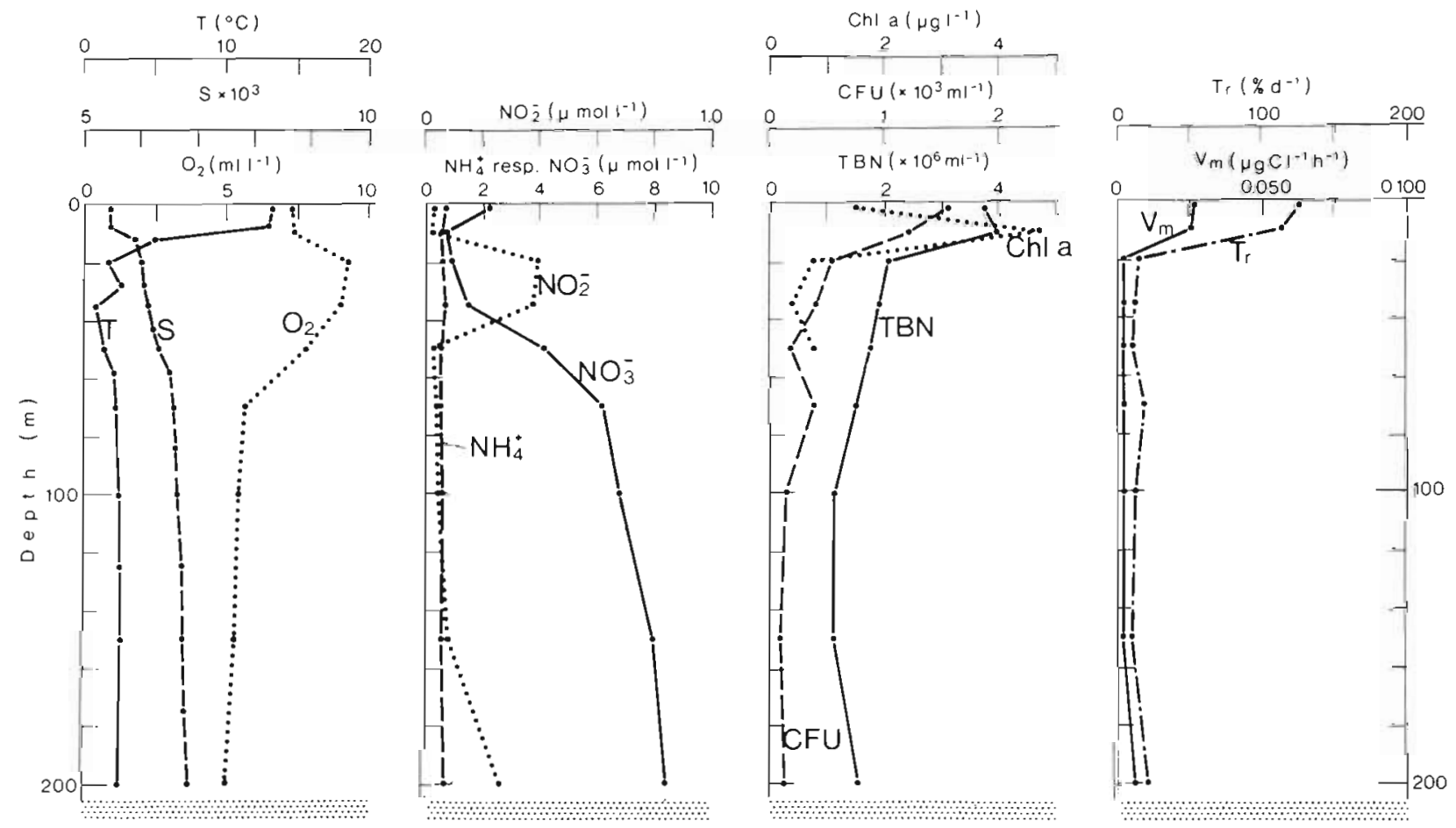

Fig. 9. Stn H, 26 Aug 1982

Bornholm Basin. Below this depth the salinity further increased, e.g. in the Gotland Deep to $12.48 \%$ on 20 Aug 1982 at $235 \mathrm{~m}$ (Fig. 6), and to $12.14 \%$ on $17 \mathrm{Aug}$ 1986 at $230 \mathrm{~m}$ (Fig. 14). In the Teili Deep on 19 Aug 1986 the different bodies of water behaved in a similar manner (Fig. 16).

This tendency was also continued in the Gulf of Bothnia, where temperature and salinity decreased still further. At the southernmost Stn G on 25 Aug 1982 values were $15.3^{\circ} \mathrm{C}$ with $5.50 \%$ at $2 \mathrm{~m}$ depth changing to $2.8^{\circ} \mathrm{C}$ with $6.3 \%$ at $50 \mathrm{~m}$ (Fig. 8 ). At the northernmost Stn J on 28 Aug 1982 values were only $13.7^{\circ} \mathrm{C}$ with $3.06 \%$ at $2 \mathrm{~m}$, and $1.6{ }^{\circ} \mathrm{C}$ with $3.50 \%$ at $50 \mathrm{~m}$ depth (Fig. 11).

\section{Oxygen and hydrogen sulfide}

In the Fehmarn Belt oxygen content on 16 Aug 1982 in the surface layer varied between 6.21 and $5.53 \mathrm{ml} \mathrm{l}^{-1}$, 

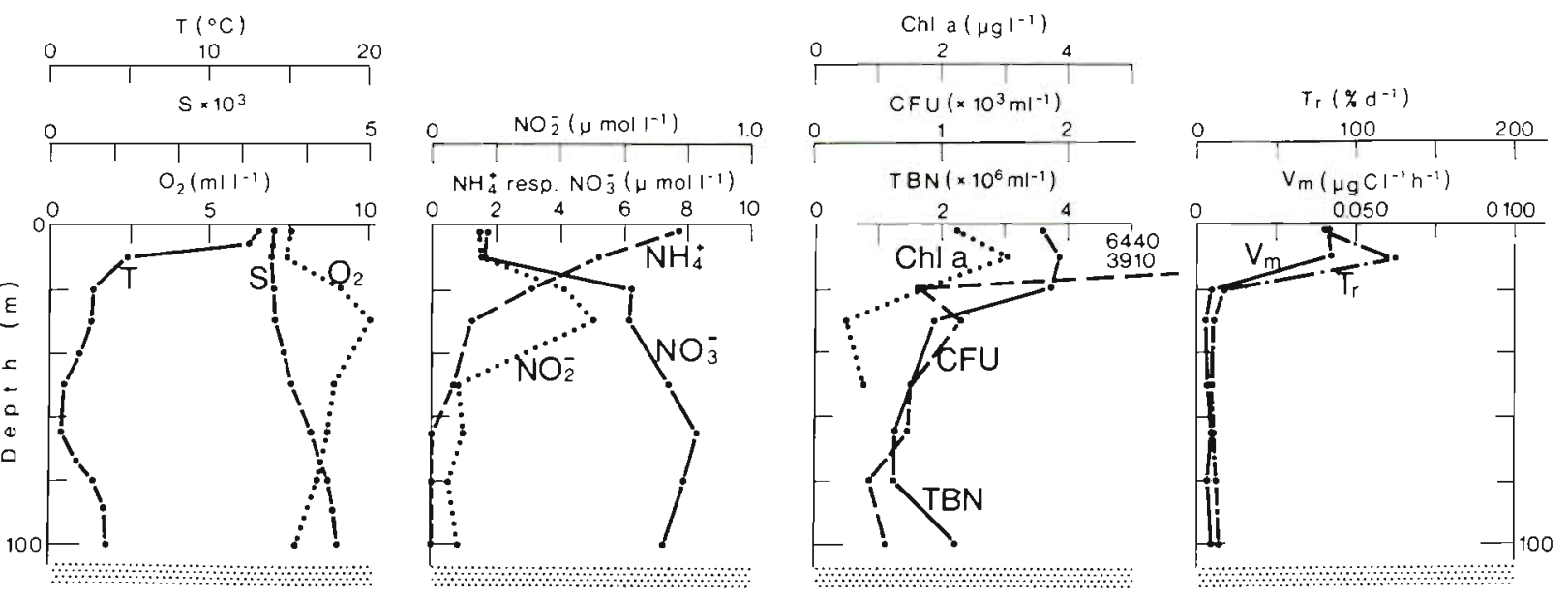

Fig. 10. Stn I, 27 Aug 1982
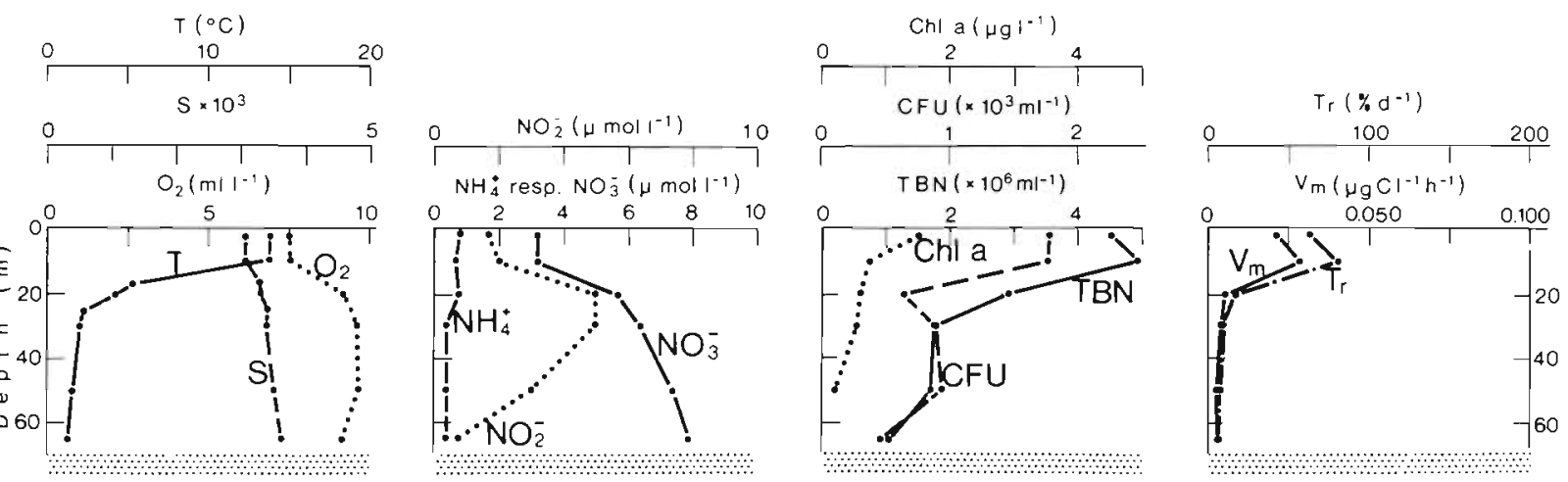

Fig. 11. Stn J, 28 Aug 1982
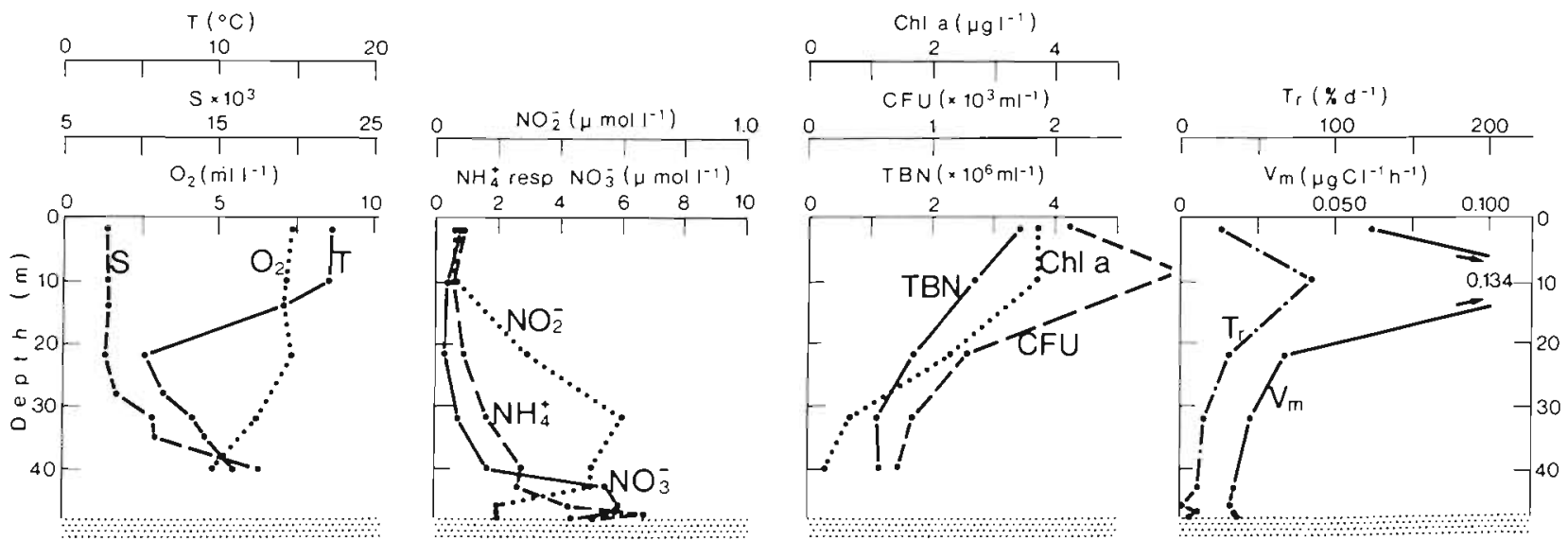

Fig. 12. Stn a (Arkona Basin), 12 Aug 1986

and dropped to $2.98 \mathrm{ml} \mathrm{l}^{-1}$ (43\% saturation) at $27 \mathrm{~m}$ depth (Fig. 2).

In the Arkona Basin the oxygen content on 17 Aug 1982 in the mixed layer ranged between 6.69 and $6.55 \mathrm{ml} \mathrm{l}^{-1}$ and decreased to $4.94 \mathrm{ml} \mathrm{l}^{-1}$ (79\% satura- tion) at $40 \mathrm{~m}$ (Fig. 3). The corresponding values on 12 Aug 1986 were $7.39,7.08$ and $4.92 \mathrm{ml} \mathrm{l}^{-1}$ (77\% saturation) and on 24 Aug 1986 were 6.94, 6.45 and $5.39 \mathrm{ml} \mathrm{l}^{-1}$ (Fig. 12), respectively. The oxygen content was relatively high in the deeper water at this station. This, as 

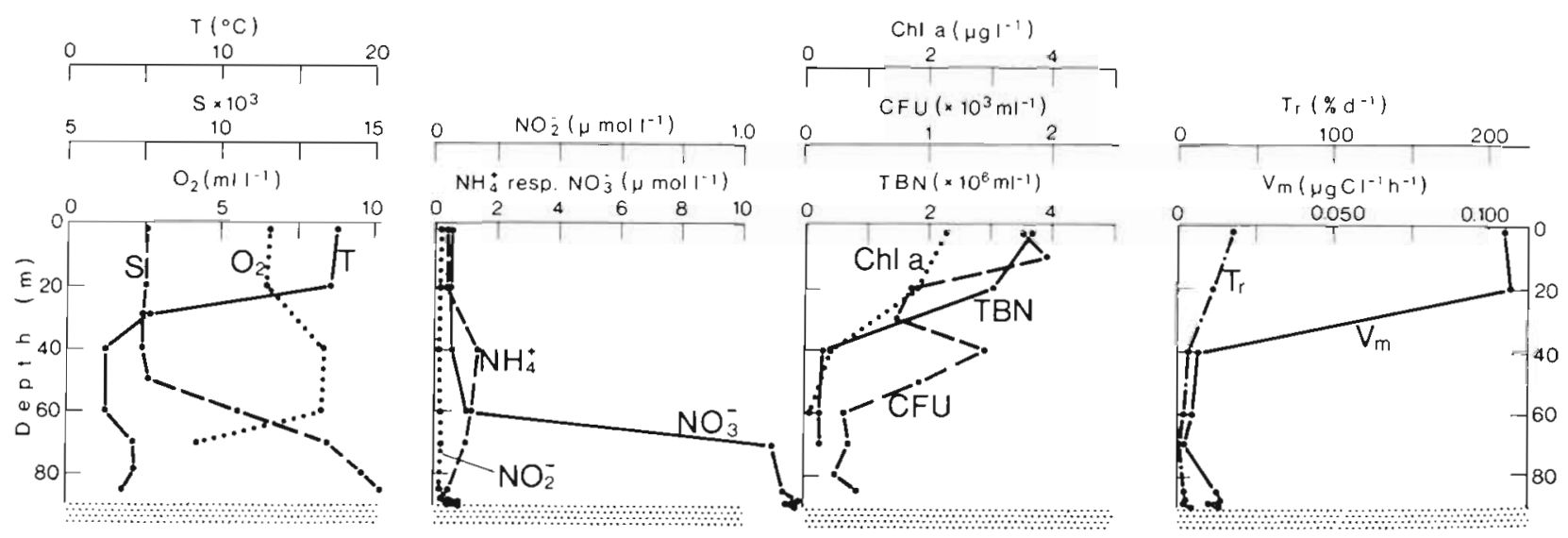

Fig. 13. Stn b (Bornholm Basin), 13 Aug 1986
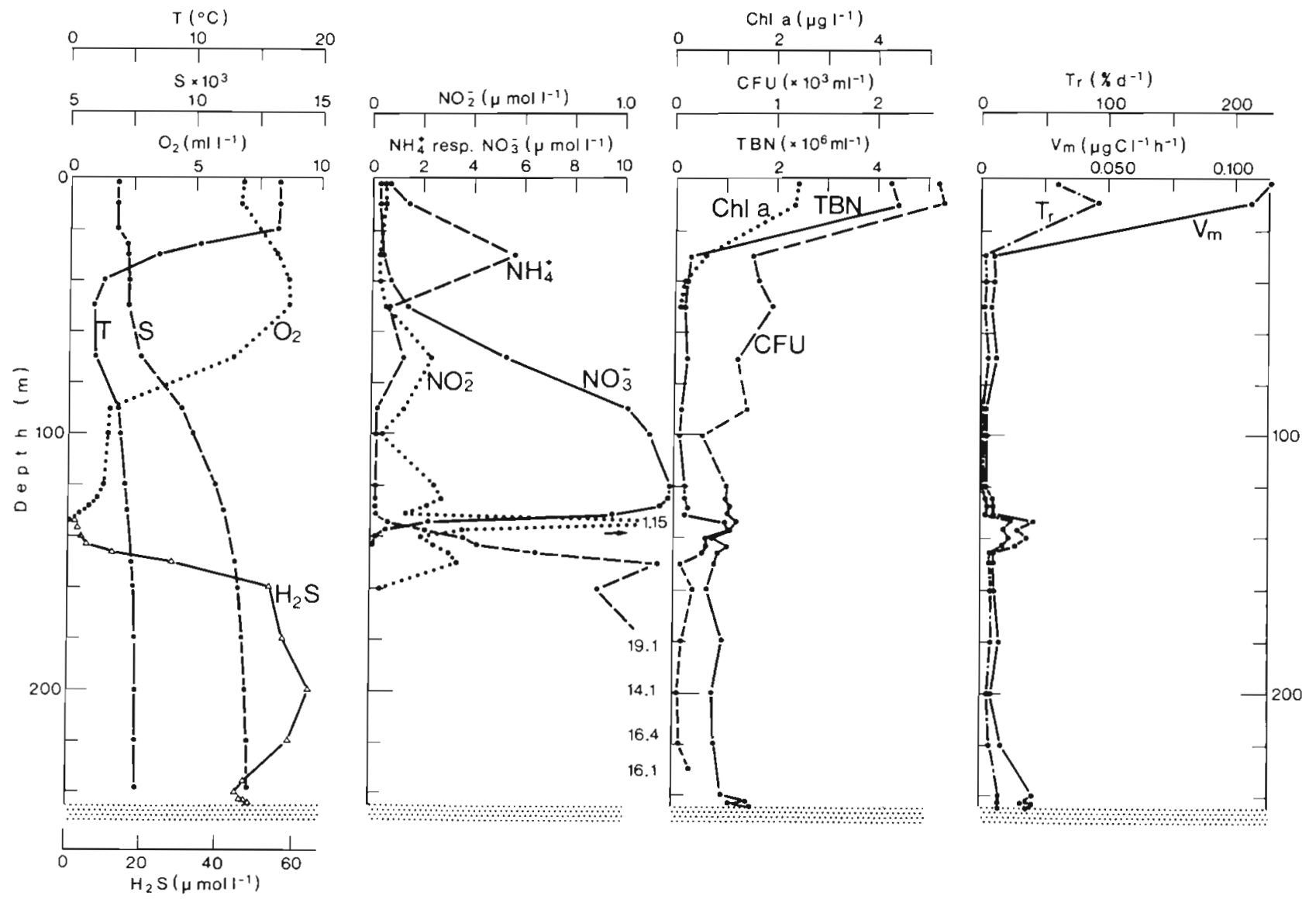

Fig. 14. Stn c (central Gotland Deep), 15 to 17 Aug 1986

well as the rise in temperature (see above), indicates a recent inflow of surface water.

At the Bornholm Basin station during both years studied and also in the southern Gotland Basin on 19 Aug 1982, conditions in the mixed layer were similar to those in the Arkona Basin. In the underlying water, the oxygen content was higher still, but then decreased strongly below 50 and $70 \mathrm{~m}$ respectively (Figs. 4 and 13).

In the Gotland and Faroe Deeps oxygen concen- trations again corresponded to those described above. Below the 'winter water' they then decreased rapidly. Between 120 and $140 \mathrm{~m}$ the anoxic zone began. In this zone hydrogen sulfide could be detected. On $17 \mathrm{Aug}$ 1986 the maximum $\mathrm{H}_{2} \mathrm{~S}$ content in the Gotland Deep, $64 \mathrm{umol} \mathrm{l}^{-1}$, was found at $200 \mathrm{~m}$ depth (Fig. 14). Below this at $230 \mathrm{~m}$ a decrease to $46 \mu \mathrm{mol} \mathrm{l}^{-1}$ occurred. In the Faroe Deep on 19 Aug 1986 the $\mathrm{H}_{2}$ S concentration rose to $45 \mu \mathrm{mol} \mathrm{l}^{-1}$ at a depth of $185 \mathrm{~m}$ (Fig. 15). 

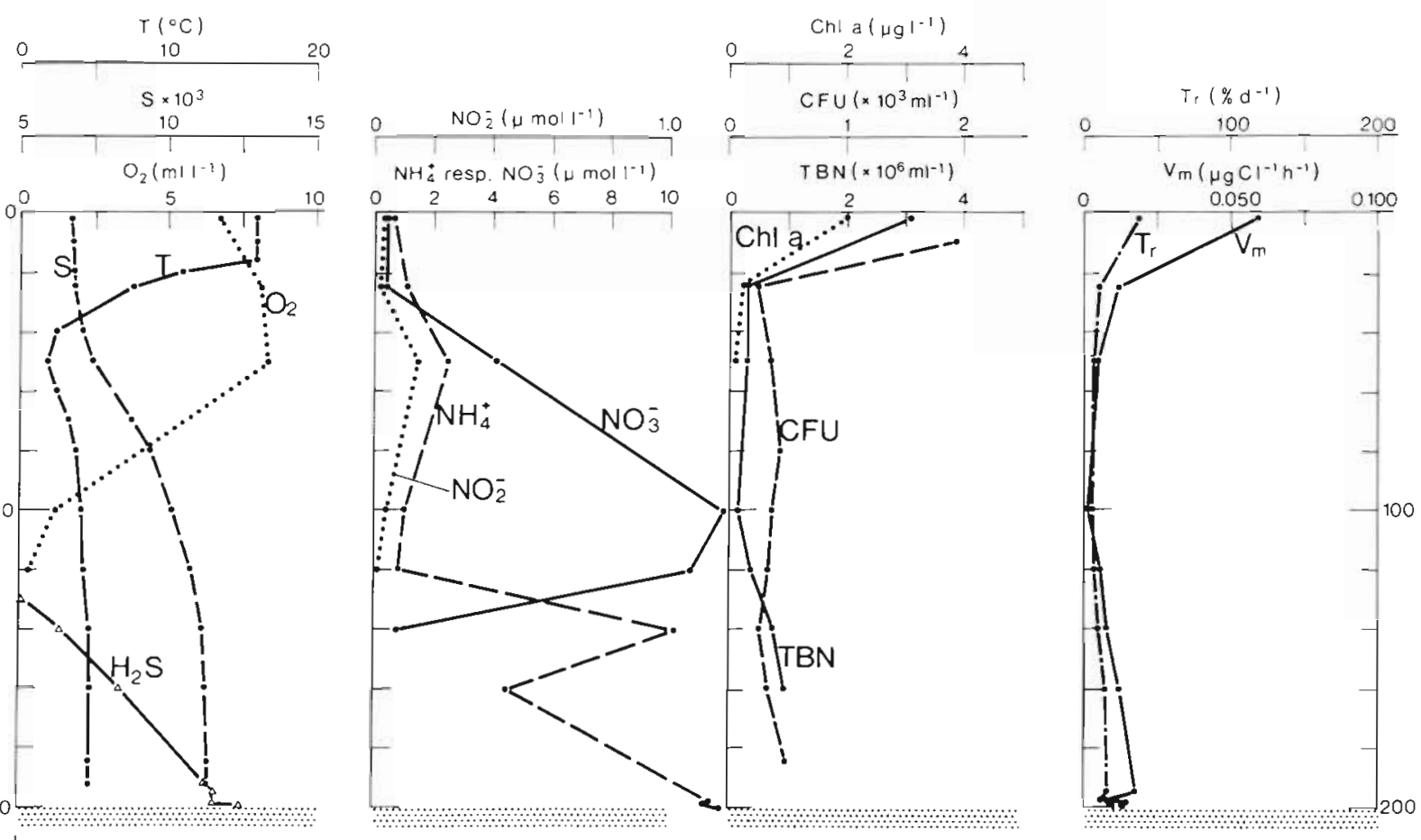

Fig. 15. Stn d (Farö Deep), 18 Aug 1986
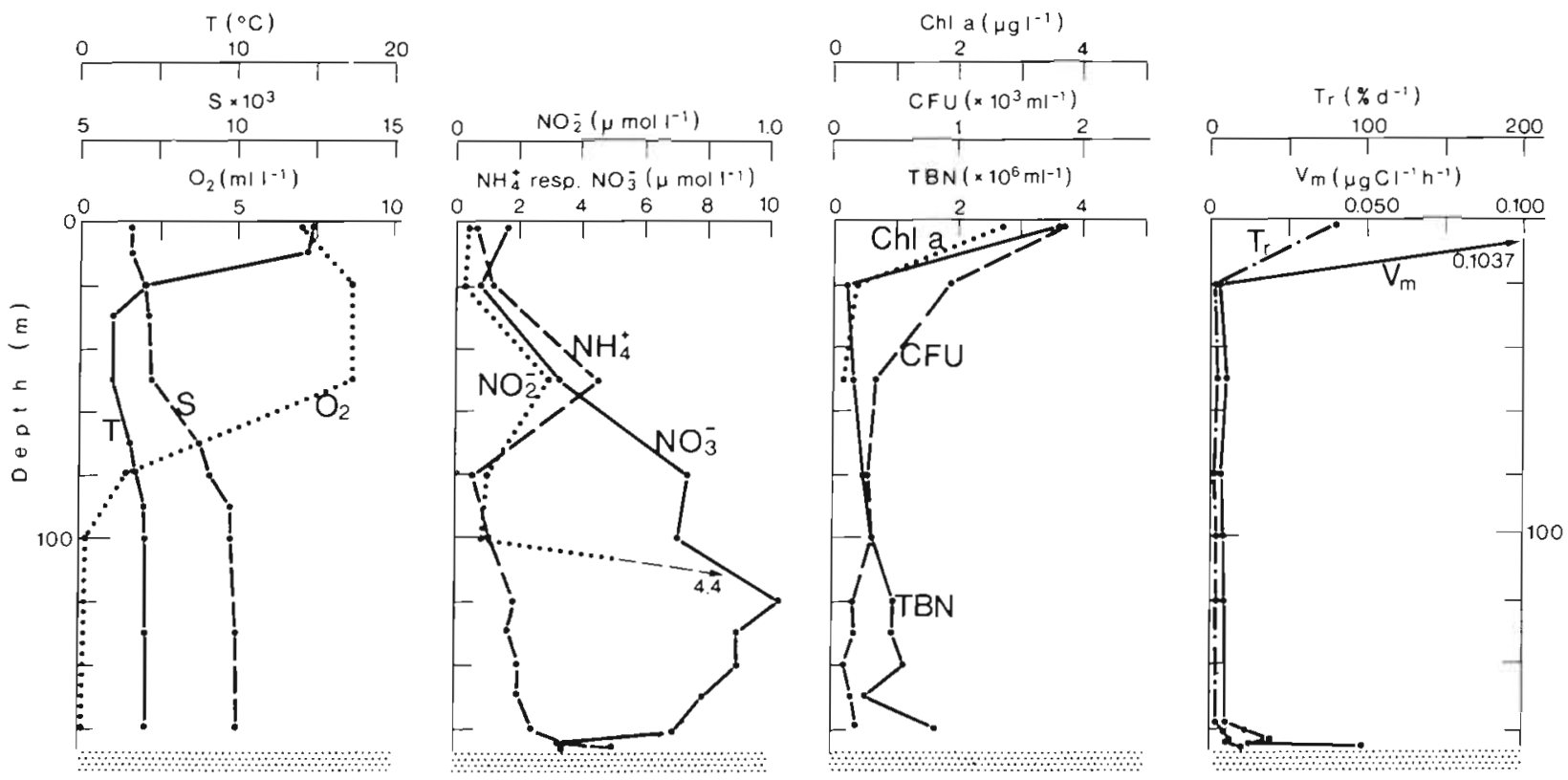

Fig. 16. Stn e (Teili Deep)، 19 Aug 1986

In the Teili Deep the oxygen content below the halocline also strongly decreased. At $100 \mathrm{~m}$ only $0.18 \mathrm{ml} \mathrm{O}_{2} 1^{-1}$ (2\% saturation) was measured. A complete disappearance, however, could not be observed, even down to a depth very close to the bottom (Fig. 16).
At all stations in the Gulf of Bothnia in August 1982 there was still a rich supply of oxygen even at greater depths (Figs. 8 to 11). At $\mathrm{Stn} \mathrm{G}$ the $\mathrm{O}_{2}$ concentration at $100 \mathrm{~m}$ was 7.17 and at $125 \mathrm{~m} 7.48 \mathrm{ml} \mathrm{l}^{-1}$, corresponding to $81 \%$ saturation (Fig. 8). Only between 30 and $50 \mathrm{~m}$ 
were the values somewhat higher, with 8.66 and $8.73 \mathrm{ml} \mathrm{O}_{2} \mathrm{l}^{-1}$ (96\% saturation). From $\mathrm{Stn} \mathrm{H}$ northwards this was already the case at $20 \mathrm{~m}$. Here the oxygen content decreased more rapidly at greater depths, however. Thus at $100 \mathrm{~m} 5.46$ and at $200 \mathrm{~m} 5.02 \mathrm{ml} \mathrm{l}^{-1}(55 \%$ saturation) were measured (Fig. 9). At Stn I, farther north, the value at $100 \mathrm{~m}$ was $7.75 \mathrm{ml} \mathrm{O}_{2} \mathrm{l}^{-1}$ (Fig. 10). The sediment at all stations investigated in the Gulf of Bothnia was aerobic at its surface. It contained numerous iron concretions and occasionally also spruce twigs.

\section{Nutrients}

In the Fehmarn Belt, silicate, orthophosphate and inorganic nitrogen compounds were present in sufficient amounts even in the mixed layer, and increased strongly above the bottom (Fig. 2).

At the Arkona Basin station on 17 Aug 1982 lower orthophosphate and nitrate values were found in the mixed layer, while those for silicate remained nearly the same (Fig. 3). Below this layer, however, there was substantially lower rise in these values than in the Fehmarn Belt. On 12 Aug 1986 (Fig. 12) nearly all nutrient values were clearly less than in August 1982.

In the Bornholm Basin on 18 Aug 1982 silicate, orthophosphate and ammonium strongly increased from $50 \mathrm{~m}$ downwards. Nitrate values were low at all depths (Fig. 4). The distribution of orthophosphate on 13 Aug 1986 was similar. Below $60 \mathrm{~m}$ nitrate showed a pronounced increase (Fig. 13). This was also true for Stn D in the southern Gotland Basin on 19 Aug 1982 (Fig. 5). Thus a nitrification zone is presumed to exist at these locations.

The stations in the Gotland and Faroe Deeps showed similar vertical distribution of nutrients, for both 1982 and 1986. At both stations the characteristic influence of oxygen deficit on the nutrient concentrations in anoxic deeper water was evident - that is, a large disappearance of nitrate by means of denitrification (Brettar 1988) and a strong increase of orthophosphate and ammonia caused by their release from the sediments (Figs. 6, 7, 14 and 15).

In the Teili Deep on 19 Aug 1986, the pronounced increase of nitrite below $100 \mathrm{~m}$ depth to $4.4 \mu \mathrm{mol} \mathrm{l}^{-1}$ was notable (Fig. 16). Here nitrate decreased very slowly between 120 and $158 \mathrm{~m}$. Orthophosphate, silicate and ammonia did not increase as strongly down to $160 \mathrm{~m}$ as was noted the previous day in the Faroe Deep.

In the Gulf of Bothnia at the end of August 1982 at Stns $G$ to $J$ an increase of the nitrite concentration could always be observed between 20 and $50 \mathrm{~m}$ depth. The nitrate concentration in the mixed layer rose clearly, proceeding from south to north; a similar pattern of nitrate distribution in this area was also reported by Gundersen (1981). At the northern Stns I and J the ammonia concentration decreased from the surface to depth. At Stn J very low orthophosphate values were measured. The vertical differences in silicate content were not as great at the northem stations as at the southern stations.

\section{Chlorophyll a}

In August 1982 the clorophyll a content in the photic zone of the western and central Baltic Sea was nearly everywhere lower than expected as there was a plankton bloom reported a few days before. With the exception of Stn A (Fehmarn Belt) values in the photic zone were around or below $2 \mu \mathrm{g} \mathrm{l}^{-1}$. In the Gulf of Bothnia, on the other hand, at $10 \mathrm{~m}$ depth higher values, up to double this amount, were found.

In August 1986 chlorophyll a concentrations in the photic zone of the western and central Baltic Sea were mostly somewhat higher, at 1.8 to $3.7 \mathrm{\mu g} \mathrm{l}^{-1}$. A phytoplankton bloom, however, was not observed at any station. Below the photic zone the chlorophyll a content in August 1986 decreased nearly everywhere more rapidly than during the same month in 1982. An example of this is given in Table 1 . The higher values from

Table 1. Chlorophyll a content at the Bornholm Basin station in summer 1982 und 1986

\begin{tabular}{|ccc|}
\hline $\begin{array}{c}\text { Depth } \\
(\mathrm{m})\end{array}$ & $\begin{array}{c}\text { 18 Aug 1982 } \\
\left(\mu \mathrm{K} \mathrm{I}^{-1}\right)\end{array}$ & $\begin{array}{c}\text { 13 Aug 1986 } \\
\left(\mu \mathrm{g} \mathrm{I}^{-1}\right)\end{array}$ \\
\hline 2 & 2.00 & 2.31 \\
10 & 2.04 & 2.36 \\
20 & 1.42 & 1.82 \\
30 & 1.27 & 1.54 \\
50 & 0.92 & 0.37 \\
70 & 0.62 & 0.10 \\
85 & 0.30 & $<0.10$ \\
\hline
\end{tabular}

the first cruise are most likely due to the above-mentioned phytoplankton bloom which had occurred just previously.

\section{Biological oxygen demand}

$\mathrm{BOD}_{7}$ was determined for all water samples in 1982 and for some of those in 1986 . Values were often less than $1 \mathrm{mg} \mathrm{l}^{-1}$. Higher values were found in many samples from Stns D, E and G as well as Stns a and C. Particularly low values occurred at the Bothnian Stns $\mathrm{H}$ and I. 


\section{Total bacteria number, bacterial biomass and saprophyte counts}

At the Fehmarn Belt station on 16 Aug 1982 (Fig. 2) quite high total bacteria numbers and a large average cell volume were determined. Biomass ranged

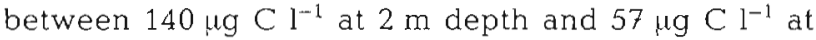
$27 \mathrm{~m}$ depth. In the upper $20 \mathrm{~m}$ the highest values during this investigation, over $100 \mu \mathrm{C}^{-1}$, were found. The saprophyte counts on ZS were between 1770 and $513 \mathrm{ml}^{-1}$. The markedly higher numbers on $\mathrm{ZS}$ in relation to ZB are due to the relatively high salinity (Rheinheimer 1985).

At the Arkona Basin station on 17 Aug 1982 (Fig. 3) total bacteria numbers were somewhat lower than in the Fehmarn Belt. Biomass varied between 91 and $51 \mu \mathrm{g} \mathrm{Cl}^{-1}$. The differences in the saprophyte counts on ZS and ZB were considerably less except for the depth with the highest salinity $(40 \mathrm{~m})$. On 4 Sept. 1982 total bacteria numbers and biomass were less than half those of 17 Aug. For the saprophyte counts this holds true only for deeper waters. On 12 Aug 1986 the biomass values were even somewhat lower; the saprophyte counts, on the other hand, especially in the photic zone, were considerably higher. Twelve days later the saprophyte counts were lower again.

In the Bornholm Basin in the upper $30 \mathrm{~m}$, very similar total bacteria numbers were found for 1982 and 1986 (Figs. 4 and 13). However, on 18 Aug 1982 average cell. volumes with 0.143 to $0.221 \mu^{3}$ were considerably larger than on $13 \mathrm{Aug} 1986$ with 0.037 to $0.066 \mathrm{\mu m}^{3}$; accordingly, biomass values were also about 3 times higher. In 1986 the saprophyte count above $50 \mathrm{~m}$ were greater and those below were less than those for 1982. Bacteriological values in the southern Gotland Basin on 18 Aug 1982 (Fig. 5) were of about the same magnitude as those in the Bornholm Basin on the previous day. Only the saprophyte counts in the upper $20 \mathrm{~m}$ were lower.

In the Gotland (Fig. 6) and Faroe Deeps (Fig. 7) the highest total bacteria numbers were found again in the mixed layer in August 1982, with about $4 \times 10^{6}$ cells $\mathrm{ml}^{-1}$. However, in the Faroe Deep the average cell volume was less than $0.1 \mu \mathrm{m}^{3}$, while that in the Gotland Deep was considerably greater. This results in corresponding lower biomass values for the former. Below the mixed layer values clearly decreased, more so in the Gotland Deep than in the Faroe Deep. In the anoxic zone there was an increase again which was more pronounced in the Faroe Deep than in the Gotland Deep (compare Figs. 6 and 7). The situation was similar in August 1986. Samples taken at closer intervals in the Gotland Deep showed an increase in the values in the boundary zone between oxic and anoxic water at around $130 \mathrm{~m}$ depth (Fig. 14). The decrease between
146 and $160 \mathrm{~m}$ was followed by an increase from $180 \mathrm{~m}$ on. Saprophyte counts in the mixed layer in 1986 were clearly higher than those in 1982. Below this layer they were of approximately the same magnitude. The distribution in the deeper water basically corresponded to the total bacteria numbers. However, in 1986, especially in the anoxic zone of the Gotland Deep, extremely low values were found $\left(<100 \mathrm{ml}^{-1}\right)$.

In the Teili Deep on 19 Aug 1986 between 20 and $100 \mathrm{~m}$, again relatively low total bacteria numbers and biomass values ( 3.66 to $5.72 \mu \mathrm{C} \mathrm{Cl}^{-1}$ ) were determined. At $120 \mathrm{~m}$ a pronounced increase was observed, especially in the bacterial biomass (up to $12.50 \mu \mathrm{g} \mathrm{C}^{-1}$ ). Below this depth down to $150 \mathrm{~m}$ a decrease was noted again to $3.53 \mu \mathrm{g} \mathrm{Cl}^{-1}$ and above the bottom an increase to $12.70 \mu \mathrm{g} \mathrm{Cl}^{-1}$. From 2 to $140 \mathrm{~m}$ depth the saprophyte counts decreased by more than 10-fold. In deeper waters a slight increase was observed (Fig. 16).

In the Gulf of Bothnia in August 1982 total bacteria numbers in the mixed layer at $S \operatorname{tn} G$ were somewhat lower than those in the Gotland and Faroe Deeps, but were of the same magnitude as at the other Bothnian stations. Biomass increased slightly going north. The saprophyte counts were in part considerably greater than those in the Baltic proper. Below $20 \mathrm{~m}$ the total bacteria numbers and biomass values were for the most part higher than in the Gotland and Faroe Deeps. The former were all above $1 \times 10^{6} \mathrm{ml}^{-1}$, while in the Gotland Deep they were always and in the Faroe Deep partly below this. Saprophyte counts below $20 \mathrm{~m}$ were likewise often somewhat higher.

\section{Bacterial activity}

Maximum uptake velocity and turnover rate of glucose

Maximum uptake velocity $\left(V_{m}\right)$ of glucose in the mixed layer during the 1982 investigation period was as follows:

Fehmarn Belt (Stn A). Here the highest values with over $0.100 \mathrm{ug} \mathrm{C} \mathrm{I}^{-1} \mathrm{~h}^{-1}$ were measured (Fig. 2).

Arkona Basin (Stn B). The $V_{m}$ in this area was distinctly lower. Values ranged from 0.050 to $0.075 \mu \mathrm{g} \mathrm{C}$ $\mathrm{l}^{-1} \mathrm{~h}^{-1}$ (Fig. 3).

Bornholm Basin to southern Gotland Basin Stns C and D). $V_{m}$ was similar to that of the Arkona Basin (Figs. 4 and 5).

Central Gotland Deep and Faroe Deep (Stns E and F). Values between 0.025 and $0.050 \mu \mathrm{g} \mathrm{Cl} \mathrm{Cl}^{-1} \mathrm{~h}^{-1}$ form a transition to the stations in the Gulf of Bothnia (Figs. 6 and 7).

Gulf of Bothnia (Stns $G$ to J). Here very low bacterial activities were measured. Only about $0.025 \mathrm{ug}$ glucose $\mathrm{C}^{-1} h^{-1}$ were taken up by the bacteria. Stn I, with 
somewhat higher values, represents an exception (Figs. 8 to 11 ).

The turnover rate of glucose in the mixed layer showed a similar pattern of distribution as $V_{m}$. Regional differences here are less pronounced, however. The highest value was $175 \% \mathrm{~d}^{-1}$ (Fehmarn Belt) while the lowest was $49 \% \mathrm{~d}^{-1}$ (Stn G). This corresponds to turnover times of 13.7 and $49 \mathrm{~h}$, respectively.

In 1982 and 1986 the regional differences of the $V_{m}$ of glucose in the Baltic proper were low. In the mixed layer, the relation between the station with the highest and the lowest $V_{m}$ was about $2: 1$. The absolute values, 0.134 (Arkona Basin) and $0.062 \mu \mathrm{g} \mathrm{C} \mathrm{l^{-1 }} \mathrm{h}^{-1}$ (Faroe Deep), in 1986 were approximately twice as high as in 1982.

In contrast to the maximum uptake velocity, the turnover rates $\left(T_{r}\right)$ of glucose in 1986 were often clearly lower than in 1982. Here the highest value, $92 \% \mathrm{~d}^{-1}$, was measured in the Gotland Deep. This corresponds to a turnover time of $26 \mathrm{~h}$. In the Bornholm Basin, where the lowest value was found, $T_{r}$ was only $35 \%$ $\mathrm{d}^{-1}$, which corresponds to a turnover time of $69 \mathrm{~h}$.

Profiles at all stations during both cruises were basically similar. In the mixed layer $V_{m}$ and $T_{r}$ were relatively high. Maximal values were often found directly at the surface; in other cases however, in the sample at the next following depth (usually $10 \mathrm{~m}$ ). The thermocline represents the lower boundary of the water layer with high microbial activity. Directly beneath this microbial activity decreased drastically and remained at a low level in the 'winter water'. The differences between the mixed layer and the 'winter water' amounted to nearly 2 orders of magnitude. The lowest values of $V_{m}$ were around $0.002 \mu \mathrm{C} \mathrm{C} \mathrm{l}^{-1} \mathrm{~h}^{-1}$ and of $T_{r}$ between 1 and $3 \% \mathrm{~d}^{-1}$, which corresponds to a turnover time of 3 to 1 mo. Differences within the winter water' at the various stations were minimal.

In 1982 in the region between the Arkona Basin and the Faroe Deep, an increase of bacterial activity was observed below the permanent halocline. This was particularly noticeable in the Arkona Basin (Fig. 3). At stations farther to the northeast, the increase was less pronounced.

During 1986 in the Gotland Deep an increase of $V_{m}$ and $T_{r}$ was measured, limited to a thin layer at the transition zone between the $\mathrm{O}_{2}$ and $\mathrm{H}_{2} \mathrm{~S}$-containing water bodies (Fig. 14). This was not observed in 1982, when the samples were taken at greater vertical intervals.

\section{Extracellular enzyme activity of bacteria}

The activity of the hydrolytic breakdown of peptides was determined only during 1982. Results for the max- imum hydrolysis velocity of the bacterial peptidases are summarized in Table 2.

As a rule peptidase activity was highest in the mixed layer In the deeper parts of the 'winter water' the activity was minimal and often lay below the detection

Table 2. Vertical profiles of extracellular peptidase activity of pelagic bacteria from different sites in the Baltic Sea, 1982. Results are maximal velocities of peptide hydrolysis as determined by the use of the model substrate Leu-MCA. Values are expressed as $V_{m}=\mu g C_{\text {leu }} 1^{-1} h^{-1}$

\begin{tabular}{|c|c|c|c|c|}
\hline $\begin{array}{c}\text { Sample } \\
\text { depth }(\mathrm{m})\end{array}$ & $\begin{array}{c}\text { Fehmarn } \\
\text { Belt }\end{array}$ & $\begin{array}{c}\text { Bornholm } \\
\text { Basin }\end{array}$ & $\begin{array}{l}\text { Gotland } \\
\text { Deep }\end{array}$ & $\begin{array}{l}\text { Faroe } \\
\text { Deep }\end{array}$ \\
\hline 2 & 0.105 & 0.082 & 0.209 & 0.241 \\
\hline 10 & 0.077 & 0.086 & 0.324 & 0.185 \\
\hline 20 & 0.041 & 0.044 & 0.064 & - \\
\hline $28^{4}$ & 0.016 & & & \\
\hline 30 & & 0.021 & - & -- \\
\hline 50 & & 0.020 & 0.054 & - \\
\hline $87^{\circ}$ & & 0.046 & & \\
\hline 100 & & & 0.022 & - \\
\hline 150 & & & & 0.113 \\
\hline $190^{4}$ & & & & 0.084 \\
\hline 200 & & & 0.194 & \\
\hline 240 & & & 0.039 & \\
\hline \multicolumn{5}{|c|}{$\begin{array}{l}\text { a Sampling depths (directly above bottom) only valid for } \\
\text { specific stations } \\
- \text { :Peptidase was below detection limit }\end{array}$} \\
\hline
\end{tabular}

limit of the method. In water samples from the zone near the sediment a slight increase in peptidase activity occurred again, with the exception of the shallow Fehmarn Belt station.

In contrast to the regional distribution of the bacterial substrate uptake, peptidase activity showed no tendency to decrease in the direction west to east. In the mixed layer it was highest in the Gotland Deep (where also the shortest 'turnover' times for peptidase were measured) and lowest in the Bornholm Basin. The rise of peptidase activity in the deeper water samples was possibly related to the depth of the basins. This was greatest in the Gotland Deep, followed by the Faroe Deep and the Bornholm Basin.

The $\beta$-glucosidase activity was also determined; however, reliable measurements could be obtained only from the mixed layer and from deep water. Measurements from the 'winter water' were always below the detection limit. A comparison of the $\beta$-glucosidase activity with the peptidase activity of these water layers shows that the peptidase activity in deep water, compared to surface water, always decreases more strongly than the $\beta$-glucosidase activity. Similar observations were reported by Kim (1985) for the Gotland Deep. 


\section{DISCUSSION}

The large differences in the hydrographic-chemical situations in the 6 areas of investigation between the Fehmarn Belt and the Gulf of Bothnia are well reflected in the bacteriological data.

The mixed layer of the sea is, apart from a few special cases, the microbiologically most active zone of the pelagial. Here organic substances are synthesized by primary producers, which are directly or indirectly utilized by heterotrophic microorganisms.

This holds true for all stations of the Baltic Sea investigated. The total bacteria numbers in the mixed layer were around $4 \times 10^{6}$ cells $\mathrm{ml}^{-1}$, whereby the range from little more than $6 \times 10^{6}$ (in the Fehmarn Belt, 1982) to about $3 \times 10^{6} \mathrm{ml}^{-1}$ (Stn G, 1982) is smaller than one might expect in an area with such widely varying regional hydrographic conditions. However, these investigations were made in late summer. During this time primary production is probably rather similar throughout the whole area. A different situation occurs at the end of April and beginning of May, when the spring phytoplankton bloom starts from the western part of the Baltic Sea (von Bodungen et al. 1981). Accordingly, in these areas higher total bacteria numbers were found than in regions where the bloom had not yet commenced (Gocke \& Hoppe 1982a, b).

The vertical distribution of physico-chemical and biological parameters observed on 17 Aug 1982 at the Arkona Basin station deserves a detailed discussion since it shows a unique feature of the western Baltic Sea. At this station the temperature of the deep water layer was nearly as high as in the mixed layer. The same was true for saprophyte numbers and the activity parameters $V_{m}$ and $T_{r}$. The chlorophyll a concentration was remarkably high in the deep water which is far below the photic zone, whereas the nitrate concentration was comparatively low. These observations lead to the conclusion that a strong inflow of high salinity water had quite recently occurred, which must have originated from the mixed layer of the central or northern Kattegat (see also Francke \& Nehring 1986). About 3 wk later (4 Sep) the situation was still nearly the same. Contrary to the situation in 1982 the findings in 1986 show a considerable aging of the deep layer indicated by the lower temperature, higher nitrate concentrations and much lower microbiological values compared to 1982 .

Of interest are also comparisons in the Bornholm Basin between 18 Aug 1982 and 13 Aug 1986. While the temperature and salinity do not show any great differences, there is a great variation in the amount of nutrients present. Only below $60 \mathrm{~m}$ can this be due to the oxygen content. At $50 \mathrm{~m}$ depth in 1982 an increase of the nitrite content to $0.28 \mathrm{\mu mol} \mathrm{I}^{-1}$ indicates a disturb- ance of the nitratation, which reacts more sensitively than the nitritation to various unfavorable factors (Rheinheimer 1985). The very low $\mathrm{O}_{2}$ concentrations below $70 \mathrm{~m}$ in August 1986 caused a disturbance also in the nitritation and probably allowed denitrification. This may explain the low nitrate concentrations.

The higher primary production, which may be deduced from the greater chlorophyll values, in the mixed layer in 1986 apparently effected an increase in the saprophyte counts - not, however, in the bacterial biomass, which was lower than in 1982. Below $30 \mathrm{~m}$ the chlorophyll contents in 1982 were greater than those of 1986 (Table 1). This could be the cause of the higher bacterial biomass values and saprophyte counts obtained from this water body.

In the Gotland and Faroe Deeps bacterial distribution and activity was determined by the stratification of the water, which was essentially the same in 1982 and 1986. Within each individual zone, however, considerable differences can often be found. Below the photic zone - between ca 40 and $120 \mathrm{~m}$ - there is a nitrification zone with a strong increase in the nitrate concentration. At about $130 \mathrm{~m}$ depth a narrow denitrification zone, comprising about $10 \mathrm{~m}$, is located, in which the nitrate is for the most part respired. This is clearly recognizable in the Gotland Deep in August 1986. where sampling took place at closer intervals. Below this depth the $\mathrm{H}_{2} \mathrm{~S}$ zone extends to the bottom.

The investigations in August 1986, during which samples were taken at close intervals $(3 \mathrm{~m})$, show that in the boundary layer (chemocline) at about $130 \mathrm{~m}$ depth, a clear increase occurs in the total bacteria number, bacterial biomass, saprophyte count, and activity. With samples taken at greater intervals, this increase could easily be overlooked. In $\mathrm{H}_{2} \mathrm{~S}$-containing deep water below $150 \mathrm{~m}$ and in bottom water, an increase of all bacteriological parameters occurs. The microbiological analysis of the water samples shows a shift towards larger cells (Gast \& Gocke 1988). The comparison of saprophyte plates incubated under aerobic and anaerobic conditions shows the dominance of facultatively and obligately anaerobic bacteria.

In the Teili Deep, the bacteriological situation in August 1986 was very different from that in the Faroe Deep. Here there exists a close correlation between bacteria and the distribution of inorganic nutrients. The oxygen content dropped to $0.18 \mathrm{ml} \mathrm{l}^{-1}$ at $100 \mathrm{~m}$ and below this lay between 0.09 and $0.15 \mathrm{ml} \mathrm{l}^{-1}$. Hydrogen sulfide could not be detected in the water, whereas in the Faroe Deep, from below $120 \mathrm{~m}$ on, $\mathrm{H}_{2} \mathrm{~S}$ was found in increasing concentrations (compare Figs, 15 and 16). The nitrate content attained its maximum (7.42 $\left.\mathrm{kmol} \mathrm{l}^{-1}\right)$ at $80 \mathrm{~m}$, and then decreased slowly to $6.85 \mu \mathrm{mol} \mathrm{l^{-1 }}$ at $158 \mathrm{~m}$. The nitrite concentration, in contrast, increased from 0.08 at $100 \mathrm{~m}$ to $4.40 \mathrm{mmol} \mathrm{l}^{-1}$. Apparently the 
second step of nitrification (nitratation) ceases, for the most part, due to the strong decrease in oxygen content (Downes 1988). It is possible that nitrate respiration in this body of water leads to a certain increase of the nitrite concentration. Actual denitrification takes place only to a small extent at most.

In the Gulf of Bothnia, high amounts of oxygen were present at all stations investigated, from the surface down to deeper water. Accordingly aerobic processes dominated throughout the water column. The nitrite peak below the mixed layer indicates a certain inhibition of nitratation in this zone. Remarkable are also the relatively high total bacteria numbers below the photic zone. Since the numerous rivers coming from northern Sweden and Finland discharge substantial amounts of terrestrial plant material and humic compounds into the sea, completely different nutrient conditions exist here. This probably causes changes in the bacterial populations. Those bacteria which are introduced from the mainland are partly inactivated in Baltic Sea water. The presence of more refractile nutrients probably exerts a major influence on the development of the bacterial flora. This is also reflected by relatively low values of maximum uptake velocity and turnover rate of glucose.

With the measurements of $V_{m}$ and $T_{r}$ in 1982, it could be shown that both these activity parameters had a larger fluctuation span than TBN. Especially in the Gulf of Bothnia, $V_{m}$ and $T_{r}$ decreased more rapidly than TBN, as compared to the Baltic proper. Possibly here a larger proportion of the bacteria population is inactive than in the Baltic proper. Since the Gulf of Bothnia is distinctly different from the other areas of the Baltic Sea in both its hydrography and its chemistry, it can be expected that the bacteria populations also have a different composition. Possibly, bacteria which are particularly adapted to substances difficult to degrade, such as humic acids, play a greater role here, whereas they are less active with regard to glucose. The temperature reduction of about $5 \mathrm{C}^{\circ}$, compared to the southern and western parts of the Baltic Sea, also contributes to the lower activity in the Gulf of Bothnia.

The low temperatures in the 'winter water' of the Baltic Sea are a fundamental reason for the very low bacterial activity in this layer. The reduction of $V_{m}$ and $T_{r}$ in the 'winter water', compared to the warm mixed layer, is more pronounced than the decrease of TBN. The low amount of organic substance available to the bacteria in this layer also plays a role. On the other hand, if organic substance is present locally, such as at the boundary layer between $\mathrm{O}_{2}$ and $\mathrm{H}_{2} \mathrm{~S}$-containing water in the Gotland Deep (Fig. 14), where chemosynthetic processes are important, bacteria number and activity clearly increase compared to adjacent water layers, in spite of the low temperatures.
Near the sediment (Figs. 14 and 16) an increase in the microbiological parameters also occasionally occurs.

The values of bacterial peptidase activity in the vertical profile follow the pattern of the heterotrophic substrate uptake. From this it can be concluded that a close coupling exists between hydrolytic breakdown of polymeric nutrients and bacterial substrate utilization during summer (Hoppe et al. 1988). In the 'winter water' peptidase activities are always extremely low. Probably refractile compounds dominate, which are very difficult to degrade.

Regionally bacterial peptidase activity shows no decreasing tendency from west to east, such as was determined for the substrate uptake. It is more likely related to TBN, which show significant fluctuations in the mixed layer, but no regional tendency.

In spite of the above-described large differences in the individual areas investigated, when considered as a whole a few common features in the bacteriological relations can be recognized. In the photic zone, which is characterized by high chlorophyll concentrations, the largest bacteria amounts and highest bacterial activity always occur. In the 'winter water' these values strongly decrease nearly everywhere. Here, however, an active nitrification already takes place. However, its 2 steps, nitritation and nitratation, do not run fully synchronously, so that a more or less clear increase in the nitrite content can be shown (Enoksson 1980).

Below the 'winter water' the bacteriological conditions in the 6 areas of investigation show pronounced differences. This is shown by the degree of oxygen depletion and hydrogen sulfide formation, which depends on the age of the water and its supply of suitable organic substances. Hydrogen sulfide formation proceeds from the sediment. It diffuses into the deeper water and spreads slowly upwards. $\mathrm{H}_{2}$ S production, which is mainly due to the sulfate-reducing bacteria, probably plays only a subordinate role in the water, as has been demonstrated for the western Baltic Sea by Bansemir \& Rheinheimer (1974). As the investigations in the Gotland Deep show, in samples taken at closer intervals, denitrification takes place only in a narrow transition zone between oxic and anoxic water (Gotland and Faroe Deeps). In the weakly oxic deep water of Teili Deep, in a wider zone, an even stronger nitrite formation occurs. As the oxygen concentration is about $0.2 \mathrm{mg} \mathrm{O}_{2} \mathrm{l}^{-1}$ ammonia oxidation (nitritation) and/or nitrate reduction could be responsible for nitrite formation (Downes 1988).

\section{LITERATURE CITED}

Bansemir, K., Rheinheimer, G. (1974). Bakteriologische Untersuchungen über die Bildung von Schwefelwasserstoff in einer Vertiefung der inneren Kieler Förde. Kieler Meeresforsch. 30: 91-98 
Bodungen, B. von, Bröckel, K. von, Smetacek, V., Zeitzschel, B. (1981). Growth and sedimentation of the phytoplankton spring bloom in the Bornholm Sea (Baltic Sea). Kieler Meeresforsch. Sonderh. 5: 49-60

Bratbak, G. (1985). Bacterial volume and biomass estimations. Appl. environ. Microbiol. 49: 1488-1493

Brettar, I. (1988). Untersuchungen zur Denitrifikation in der zentralen Ostsee. Dissertation, Univ. Kiel

Daubner, I. (1972). Mikrobiologie des Wassers. Akademie Verlag, Berlin

Dawson, R., Gocke, K. (1978). Heterotrophic activity in comparison to the free amino acid concentration in Baltic Sea water samples. Oceanologica Acta 1: 45-54

Deutsche Einheitsverfahren zur Wasser-, Abwasser- und Schlammuntersuchung. Verlag Chemie, Weinheim

Downes, M. T (1988). Aquatic nitrogen transformations at low oxygen concentrations. Appl. environ. Microbiol. 54: $172-175$

Enoksson, V. (1980). Nitrification in marine ecosystems. In: Rosswall (ed.) Processes in the nitrogen cycle. Swedish Environmental Protection Board, Stockholm, PM 1213, p. $157-166$

Ferguson, R. E., Rublee, P. (1976). Contribution of bacteria to standing crop of coastal plankton. Limnol. Oceanogr. 21: $141-145$

Francke, E., Nehring, D. (1986). The salt water influx in autumn 1982 and winter 1982/83 - the beginning of the renewed change in the marine environment of the Baltic Sea in 1983. In: Ecological investigations of the Baltic Sea. Intern. Symp. Riga, USSR, 1983. Gidromet, Leningrad, $148-160$

Gast, V., Gocke, K. (1988). Vertical distribution of number, biomass and size-class spectrum of bacteria in relation to oxic/anoxic conditions in the Central Baltic Sea. Mar. Ecol. Prog. Ser. 45: 179-186

Gocke, K. (1977). Untersuchungen über die heterotrophe Aktivität in der zentralen Ostsee. Mar. Biol. 40: 87-94

Gocke, K., Hoppe, H.-G. (1982a). Entwicklung von Bakterienzahl und -aktivität während einer Fruhjahrsblüte des Phytoplanktons in der Ostsee. Botanica mar. 25: 295-303

Gocke, K., Hoppe, H.-G. (1982b). Regionalverteilung der Bakterienzahl und -aktivität in der mittleren Ostsee. Botanica mar. 25: 381-389

Grasshoff, K. (1964). Über eine empfindliche direkte Methode zur automatischen und manuellen Bestimmung von Ammoniak im Meerwasser. Z. analyt. Chem. 234: 13-22

Grasshoff, K. (1968). Zur Bestimmung von Nitrat in Meer- und Trinkwasser. Kieler Meeresforsch. 20: 5-11

Grasshoff, K. (1976). Methods in sea water analysis. Verlag Chemie Weinheim New York

Gundersen, K. (1981). The distribution and biological transfor-

This article was presented by Dr W. Gunkel, Helgoland, F.R Germany mations of nitrogen in the Baltic Sea. Mar Pollut. Bull. 12 199-205

Hoppe, H.-G. (1983). Significance of exoenzymatic activities in the ecology of brackish water: measurements by means of methylumbelliferyl-substrates. Mar. Ecol. Prog. Ser. 11 299-308

Hoppe, H.-G., Kim, S.-Jin, Gocke, K. (1988). Microbial decomposition in aquatic environments: combined process of extrazellular enzyme activity and substrate uptake. Appl. environ. Microbiol. 54: 784-790

Kim, S.-J. (1985). Untersuchungen zur heterotrophen Stoffaufnahme und extrazellulären Enzymaktivität von freilebenden und angehefteten Bakterien in verschiedenen Gewässerbiotopen. Dissertation, Univ. Kiel

Murphy, J., Riley, J. P. (1962). A modified single solution method for the determination of phosphate in natura waters. Analytica chim. Acta 27: 31-36

Nehring, D. (1981). Hydrographisch-chemische Untersuchungen in der Ostsee von 1969-1978. II. Die chemischen Bedingungen und ihre Veränderungen unter besonderer Berücksichtigung des Nährstoffregimes. Geod. Geoph. Veröff. R IV, 35: 39-220

Nehring, D., Francke, E. (1981). Hydrographisch-chemische Untersuchungen in der Ostsee 1969-1978. I. Die hydrographischen Bedingungen und ihre Veränderungen Geod. Geoph. Veröff. R IV, 35: 5-38

Rheinheimer, G. (ed.) (1977). Microbial ecology of a brackish water environment. Ecological Studies 25. Springer, Berlin

Rheinheimer, G. (1984). Bacterial ecology of the North and Baltic Seas. Botanica mar. 27, 277-299

Rheinheimer, G. (1985). Mikrobiologie der Gewässer. (4. Aufl.) Fischer Jena, Stuttgart

SCOR-UNESCO (1966). Determination of photosynthetic pigments. In: Monographs on oceanographic methodology. Rep. Work. Group No. 17, UNESCO, Paris

Seppänen, H., Voipio, A. (1971). Some bacteriological observations made in the northern Baltic. Merentutkimuslait. Julk/Havsforskningsinst. Skr. 233: 43-48

Tsiban, A., Panov, G. V., Daksh, L. V., Jurskowskaya, V A. (1980). Bacterial population of the open waters of the Baltic Sea. In: Investigations of the ecosystem of the Baltic Sea. I. Results of the Soviet-Swedish Expedition in the Baltic Sea. Hydromet

Wright, R. T., Hobbie, J. E. (1966). Use of glucose and acetate by bacteria and algae in aquatic ecosystems. Ecology 47 : $447-464$

Zimmermann, R. (1977). Estimation of bacterial number and biomass by epifluorescence microscopy and scanning electron microscopy. In: Rheinheimer, G.: Microbial ecology of a brackish water environment. Ecological Studies 25. Springer, Berlin, p. 103-120

Manuscript received: October 10,1988

Revised version accepted: December 9, 1988 